\title{
Factors promoting larch dominance in central Siberia: fire versus growth performance and implications for carbon dynamics at the boundary of evergreen and deciduous conifers
}

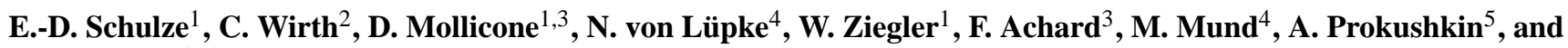 \\ S. Scherbina ${ }^{6}$ \\ ${ }^{1}$ Max-Planck Institute for Biogeochemistry, P.O. Box 100164, 07701 Jena, Germany \\ ${ }^{2}$ Institute of Biology, University of Leipzig, Johannisalle 21-23, 04103 Leipzig, Germany \\ ${ }^{3}$ Institute of Environment and Sustainability, Joint Research Centre - TP440, 21027 Ispra, Italy \\ ${ }^{4}$ Dept. of Ecoinformatics,Bioemetrics and Forest Growth, University of Göttingen, Büsgenweg 4, 37077 Göttingen, Germany \\ ${ }^{5}$ V. N. Sukachev Institute of Forest, SB-RAS, Krasnoyarsk, Russia \\ ${ }^{6}$ Centralno-Sibirsky Natural Reserve, Bor, Russia
}

Correspondence to: E.-D. Schulze (detlef.schulze@bgc-jena.mpg.de)

Received: 3 November 2011 - Published in Biogeosciences Discuss.: 2 January 2012

Revised: 5 March 2012 - Accepted: 13 March 2012 - Published: 16 April 2012

\begin{abstract}
The relative role of fire and of climate in determining canopy species composition and aboveground carbon stocks were investigated. Measurements were made along a transect extending from the dark taiga zone of central Siberia, where Picea and Abies dominate the canopy, into the Larix zone of eastern Siberia. We test the hypotheses that the change in canopy species composition is based (1) on climate-driven performance only, (2) on fire only, or (3) on fire-performance interactions. We show that the evergreen conifers Picea obovata and Abies sibirica are the natural late-successional species both in central and eastern Siberia, provided there has been no fire for an extended period of time. There are no changes in performance of the observed species along the transect. Fire appears to be the main factor explaining the dominance of Larix and of soil carbon. Of lesser influence were longitude as a proxy for climate, local hydrology and active-layer thickness. We can only partially explain fire return frequency, which is not only related to climate and land cover, but also to human behavior.

Stand-replacing fires decreased from 300 to $50 \mathrm{yrs}$ between the Yenisei Ridge and the upper Tunguska. Repeated non-stand-replacing surface fires eliminated the regeneration of Abies and Picea. With every 100 yrs since the last fire, the percentage of Larix decreased by $20 \%$.
\end{abstract}

Biomass of stems of single trees did not show signs of age-related decline. Relative diameter increment was $0.41 \pm 0.20 \%$ at breast height and stem volume increased linearly over time with a rate of about $0.36 \mathrm{tC} \mathrm{ha}^{-1} \mathrm{yr}^{-1}$ independent of age class and species. Stand biomass reached about $130 \mathrm{tC} \mathrm{ha}^{-1}$ (equivalent to about $520 \mathrm{~m}^{3} \mathrm{ha}^{-1}$ ). Individual trees of Larix were older than $600 \mathrm{yrs}$. The maximum age and biomass seemed to be limited by fungal rot of heart wood. $60 \%$ of old Larix and Picea and $30 \%$ of Pinus sibirica trees were affected by stem rot. Implications for the future role of fire and of plant diseases are discussed.

\section{Introduction}

Siberia is characterized by evergreen forests of spruce, pine and fir in western Siberia and along the Yenisei Ridge, but by deciduous forest of larch in central and eastern Siberia, and in the arctic zone. The border between these two functional types is mechanistically not understood and currently prescribed by bioclimatic limits. For example, the widely used LPJ-model generates the dominance of larch (Larix) in eastern Siberia by using a minimum annual temperature range of $43^{\circ} \mathrm{C}$ (Sitch et al., 2003). This parameterization was fit to match the current distribution of Larix in far east Siberia. The 
same parameters are used in several other global dynamic vegetation models such as ORCHIDEE (Krinner et al., 2005) or SEIB-DGVM (Sato et al., 2007). Similarly, the FAREAST model allows for a very low growing season length for Larix compared to other Siberian conifers (Xiaodong and Shugart, 2005; Shuman et al., 2011). However, larch has many additional features which promote its existence under the harsh conditions in eastern and northern Siberia such as the growth of adventitious roots (Schulze et al., 2002) which is of advantage on permafrost and bogs. This feature has been implemented in LPJ by allowing the plant functional type of boreal needle-leaved summergreen trees (i.e. Larix sp.) to adjust its fine root layer to the dynamics of the active layer thus additionally increasing its drought tolerance (Beer et al., 2007). It has also been suggested that the deciduous foliage may be of advantage at extreme winter temperatures and during periods of frost drought (Schulze, 1982). Given these diverse adaptations, it has been suggested that larch dominates in eastern Siberia, because it is the only tree species capable of enduring the harsh climatic conditions (Sugimoto et al., 2002).

However, the separation between deciduous and evergreen regions may not be as clear as many vegetation maps imply. Distribution maps of tree species show that coniferous evergreen species also persist in eastern Siberia. The Siberian spruce (Picea obovata) and the Siberian stone pine (Pinus sibirica) can grow on permafrost, although they dominate only along water flows where the active layer tends to be deeper (Nikolov and Halmisaari, 1992), even though Picea obovata was generally present in the understory of Larix forests even far away from water flows (Schulze et al., 1995). Scots pine (Pinus sylvestris) occupies dry habitats throughout Siberia (Walter, 1974). Thus, besides temperature and the associated length of growing season and permafrost, there seem to be additional factors which determine the distribution and abundance of evergreen and deciduous conifers in Siberia.

Fire is an additional important factor controlling species composition and carbon stocks in pine and spruce forests (Mollicone, 2002; Schulze et al., 2005). Typically in the northern Siberian taiga, forest stands become established only after a major stand-replacing fire event. In addition, Siberian forests generally experience a number of repeated surface fires during their life cycle, yet boreal tree species differ greatly in their susceptibility to fire damage. Beyond a certain size threshold Siberian "light taiga" Larix species typically become fire-resistant through the development of a thick bark and by shedding low-reaching branches that otherwise would serve as a fuel-ladder (Wirth, 2005). With respect to fire tolerance Larix is similar to Pinus sylvestris, which is just as fire tolerant (Wirth et al., 1999), and this contrasts to the typical evergreen "dark taiga" species, Siberian spruce (Picea obovata), Siberian fir (Abies sibirica) and, to a lesser extent, Siberian stone pine (Pinus sibirica), which do not show these morphological adaptations and which are killed even by low intensity surface fires. Fire tolerance makes Larix species and Pinus sylvestris distinct not only in Siberian forests but also in comparisons with the boreal forests of Alaska (Bond-Lamberti et al., 2007; Wirth, 2005). These differences in fire tolerance are neither depicted in the baseline version of LPJ (Sitch et al., 2003) nor in the improved LPJ fire module SPITFIRE where the boreal summergreen conifers are parameterized to have thinner bark and thus lower fire tolerance than wintergreen conifers (Thonicke et al., 2010).

With this paper we explore the relative roles of fire and climate-driven differences in tree performance in determining canopy species composition and carbon stocks along a large-scale transect extending from the dark taiga zone of central Siberia into the Larix zone of eastern Siberia along the Podkamenaya Tunguska river. We test hypotheses based on the following three scenarios:

1. "Performance only": if there was a physiological or morphological basis for the dominance of Larix in eastern Siberia this would be reflected by an increase in performance of Larix (growth rates, regeneration) relative to the dark taiga species towards the east. Stand composition would not be related to fire history but only to climatic and edaphic factors. In this context it remains unclear which climatic factor controls biogeography. Here we use longitude as surrogate for "continentality" which includes changes in temperature and rainfall regime because climate data of the study region are confined to very few locations and contain various uncertainties. The local microtopography was described by a hydrology index.

2. "Fire only": if the dominance of Larix was driven by differences in fire regime and differential fire effects on mortality the relative abundance (or biomass) of Larix would be inversely related to the time since the last fire, implying that in the absence of fire dark taiga species can take over even inside the Larix zone. Under this scenario, we would not expect to find changes in performance of the species along the gradient and the progressive dominance of Larix towards the east should be associated with a concurrent shortening of the fire cycle. Fires include natural and anthropogenic events (Mollicone et al., 2006).

3. "Interaction": both factors interact along the transect inducing a gradual shift in species composition from dark taiga to Larix-dominated forest vegetation.

To test these hypotheses, we focus on comparing mainly old-growth stands, which are considered to be in equilibrium with the soils and climatic conditions along the whole longitudinal transect. These old-growth stands will have experienced different fire frequencies and different lengths of time since the last ground-fire. We specifically investigate stand 


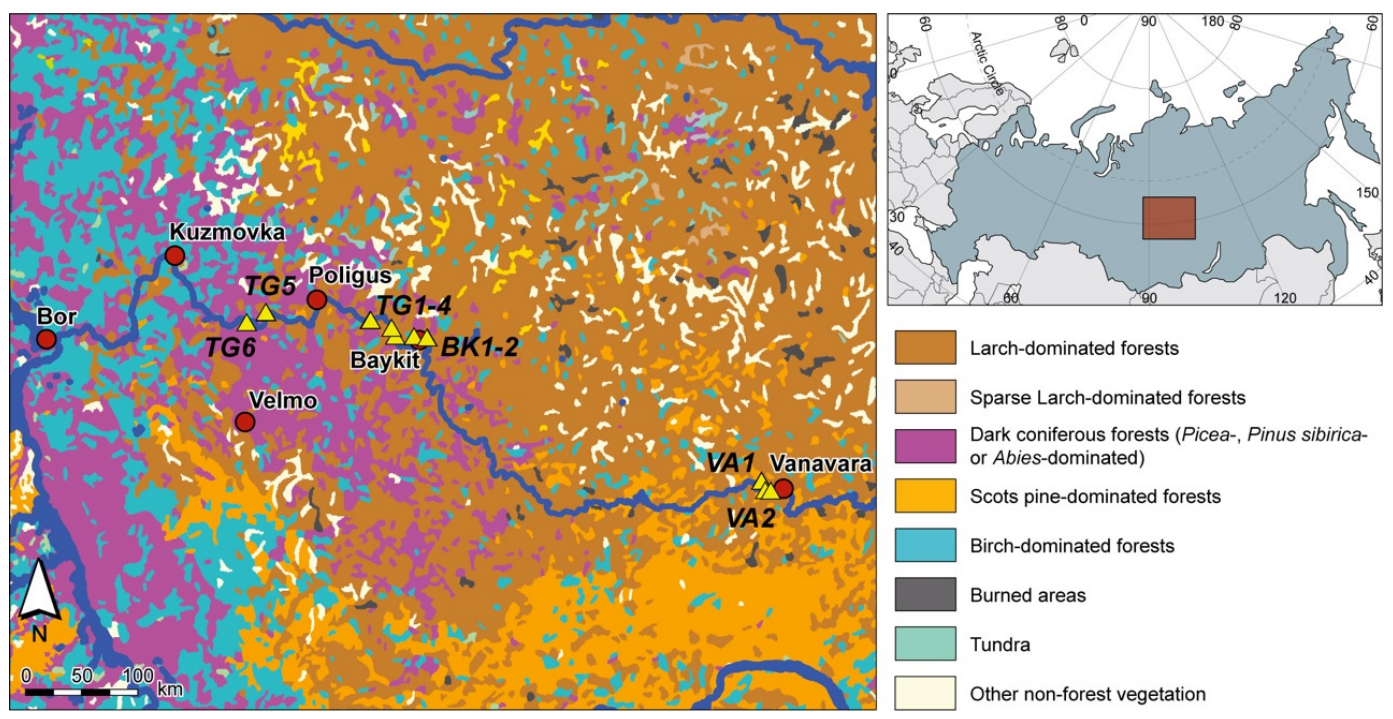

Fig. 1. Vegetation map (Isaev, 1990) and study sites at $60^{\circ} \mathrm{N}$ and east of $90^{\circ} \mathrm{E}$ as determined from satellite images (see site; chapter site selection). The main settlements are Bor, Kuzmovka, Velmo, Poligus, Baykit and Vanavara. The latter 4 settlements also served meteorological stations (see Table 1). The study sites are indicated as VA (Vanavara), BK (Baikit) and TG (Tunguska).

composition (deciduous versus evergreen conifers) and associated carbon stocks in the biomass and the organic layer. These variables change in the transition zone between evergreen dark taiga and deciduous light taiga east of the River Yenisei that runs from the Yenisei Ridge through the Siberian Plateau. The Yenisei Ridge (Shibistov and Schulze, 2007) is the first mountain range east of the West Siberian Depression, which increases the rainfall from about $530 \mathrm{~mm}$ in the West Siberian Plain (Schulze et al., 2002) to about $730 \mathrm{~mm}$ on the rise of the mountain ridge. Rainfall decreases again to below $500 \mathrm{~mm}$ east of the mountain range on the Siberian Plateau. The Yenisei Ridge is covered by Siberian dark taiga (Mollicone et al., 2002). Towards the east various Larix species become dominant, although patches of mixed and evergreen forest persist. In this paper we investigate species composition, and carbon stocks and accumulation on 16 study plots following the River Podkamennaya Tunguska $\left(61^{\circ}\right.$ to $64^{\circ} \mathrm{N}$, $90^{\circ}$ to $107^{\circ} \mathrm{E}$ ) which is a very remote area of study.

This study is complementary to previous investigations in which we studied the effects of fire on pure Larix gmelinii forest in Yakutsk (Schulze et al., 1995), on Pinus sylvestris forests in western Siberia (Wirth et al., 1999, 2002) and on the dark taiga vegetation of the Central Siberian Plateau (Schulze et al., 2005). The study also contributes to our understanding of the carbon cycle of Siberian forest and the performance of old-growth stands of Siberian Larix. Thus, our focus is on understanding of vegetation patterns rather than explaining fire frequency. Our study is confined to the southern boarder of permafrost and is complementary to observations on Larix forest in the northern (Kharuk et al., 2011) and eastern (Schulze et al., 1995) permafrost regions.

\section{Study area}

The study area (Fig. 1) reaches from the settlement of Vanavara $\left(60.33^{\circ} \mathrm{N}, 102.27^{\circ} \mathrm{E}\right)$ in the east, about $700 \mathrm{~km}$ east of the River Yenisei, to the central part of the mountain range 100 to $300 \mathrm{~km}$ east of the Yenisei along the River Podkamennaya Tunguska $\left(60^{\circ}\right.$ to $63^{\circ} \mathrm{N}, 90^{\circ}$ to $\left.103^{\circ} \mathrm{E}\right)$. The longitudinal transect covers a total distance of about $600 \mathrm{~km}$ with a focus on forest vegetation along the east slope of the mountain range. The study region is difficult to reach. There is no roadsystem and there are only two airports (Vanavara, Bajkit). The only access is by boat along the River Tunguska and then by foot. Locally, the region is becoming increasingly developed due to mining for oil and gas.

The Podkamennaya Tunguska runs parallel to the southern border of the continuous permafrost zone, which in this region is characterized by patches of frozen and non-frozen ground (Kondrotiva, 1986). The river then cuts through the mid-Siberian mountain ridge at Bajkit to merge as the third largest tributary with the Yenisei. The vegetation of the Yenisei Ridge is characterized by dark taiga forest dominated by Abies sibirica Lebed., Picea obovata Lebed. and Pinus sibirica DuTour, which follow an early successional stage of Betula ssp. and Populus tremula L. after stand-replacing fire (Schulze et al., 2005). Beyond the main divide, the dark taiga is increasingly replaced by Larix, which may form large monotypic forest stands. Larix forests extend from central Siberia to the far eastern edge of Siberia. Fire frequency is expected to be higher east of the Yenisei Ridge (Kharuk et al., 2005b), and will studied as a driver of forest composition in this study. 
Table 1. Long-term averages of precipitation $(P)$ and temperature $(T)$ along the River Tunguska.

\begin{tabular}{|c|c|c|c|c|c|c|c|c|}
\hline \multirow[t]{2}{*}{ Location } & \multirow[t]{2}{*}{ Longitude } & \multirow[t]{2}{*}{ Latitude } & \multirow[t]{2}{*}{$\begin{array}{l}\text { Elevation } \\
(\mathrm{m})\end{array}$} & \multicolumn{2}{|c|}{$\begin{array}{c}\text { Precipitation }(\mathrm{mm}) \\
1932-1999\end{array}$} & \multicolumn{2}{|c|}{$\begin{array}{c}\text { Temperature }\left({ }^{\circ} \mathrm{C}\right) \\
1932-1999\end{array}$} & \multirow[t]{2}{*}{ Remark } \\
\hline & & & & annual & summer & annual & summer & \\
\hline Vanavara & $102^{\circ} 16.2^{\prime}$ & $60^{\circ} 19.8^{\prime}$ & 248 & $407 \pm 71$ & $163 \pm 51$ & $\begin{array}{l}-13.37 \\
\pm-12.00\end{array}$ & $6.73 \pm 7.55$ & $\begin{array}{l}\text { no trend in precipita- } \\
\text { tion, summer tempera- } \\
\text { ture above av. last } 15 \mathrm{yrs}\end{array}$ \\
\hline Bajkit & $96^{\circ} 22.2^{\prime}$ & $61^{\circ} 40.2^{\prime}$ & 441 & $490 \pm 72$ & $177 \pm 45$ & $\begin{array}{l}-12.52 \\
\pm-11.12\end{array}$ & $7.92 \pm 5.58$ & $\begin{array}{l}\text { no trend in precipita- } \\
\text { tion, summer tempera- } \\
\text { ture above av. last } 15 \mathrm{yrs}\end{array}$ \\
\hline $\begin{array}{l}\text { Velmo, } \\
\text { Poligus, } \\
\text { Kuzmovka }\end{array}$ & $\begin{array}{l}93^{\circ} 25.2^{\prime} \\
94^{\circ} 37.9^{\prime} \\
92^{\circ} 07.0^{\prime}\end{array}$ & $\begin{array}{l}61^{\circ} 01.2^{\prime} \\
61^{\circ} 59.1^{\prime} \\
62^{\circ} 18.5^{\prime}\end{array}$ & 133 & $\begin{array}{l}407 \pm 71 \\
567-594 \\
663-806\end{array}$ & $\begin{array}{l}163 \pm 51 \\
181-224 \\
130-302\end{array}$ & No data & No data & decrease in precipitation \\
\hline
\end{tabular}

Our study is based on an intensive survey of Landsat images (Mollicone, 2002; Mollicone et al., 2002) which indicated that patches of evergreen forests exist within the Larixdominated region. These patches appeared to represent oldgrowth stands at the eastern end of our study zone where Larix-forests dominate.

In this study we refer to Larix as a group of species that can only be distinguished by their cones. Larix gmelinii (Rupr.) Kunzen is a species dominating in the far east of Siberia. Larix sibirica Lebed. is a species forming the western and arctic range of Larix, and Larix czekanowskii Sukacz. \& Lamak. is a hybrid between these two main species found along River Tunguska. Also birch (Betula) is represented by two species, where Betula pendula Roth. replaces Betula pubescens Ehrh. east of Bajkit (Nikolov and Halmisaari, 1992).

There are only few weather stations in the study region (Fig. 1), and some of these have only operated for a short period of time (e.g. Poligus and Kuzmovaka). We refer to Vanavara, Bajkit, and Velmo (Table 1). Velmo is located in the middle of the Central Siberian Plateau, $70 \mathrm{~km}$ south of the River Tunguska on a north-south running contributory. The station may thus be in the rain-shadow of the western mountain ridge, possibly leading to an underestimation of the regional rainfall. Poligus and Kuzmovaka, that are settlements near the River Tunguska, have only short runs of precipitation data. Total rainfall decreased from $600 \mathrm{~mm}$ in the west to $400 \mathrm{~mm}$ in the east, even though summer rainfall appears to be surprisingly similar for all sites. The higher annual rainfall over the mountain range is mainly snow, which may run off at snow melt on frozen soil (Kelliher et al., 1997). There is also no significant trend in temperature or precipitation in the annual record from 1932 to 1999 (not shown).

Soils were generally cambisols with varying thicknesses of the active layer. None of the studied cambisols had signs of podsolization or reduced iron-oxides. Bedrock was basalt at a depth below $70 \mathrm{~cm}$. The thickness of the organic layer varied between 3 and $16 \mathrm{~cm}$.
Our main study regions and sites are, from east to west (Fig. 1, Table 2):

- Vanavara

Located about $18 \mathrm{~km}$ west of the Vanavara settlement in the Meteorite National Park. Wetlands and rivers saved this site even from the regional wind-throw generated by the Tunguska meteorite in 1908. Soils are wet cambisols with ice formation (permafrost) in layers at $40 \mathrm{~cm}$ depth. Total soil formation was deeper than the layers containing ice.

\section{- Bajkit}

The main settlement before the River Tunguska cuts through the Central Siberian Plateau. The study site is located on top of an old riverbank along the winter road leading to the east. Sites with variable contribution of deciduous and evergreen canopy trees were studied in this region. Larix czekanowskii dominates these forests. Soils were cambisols with ice layers at $60 \mathrm{~cm}$ depth.

\section{- Tunguska Canyon}

The river cuts a canyon-like path through the Yenisei Ridge (site: Tunguska 1 to 6). Going from west to east, there is a transition from evergreen conifers towards Larix sibirica-dominated forest. Soils were cambisols with ice layers at 70 to $80 \mathrm{~cm}$ depth.

\section{Site selection}

Testing our hypotheses required the study of tree species performance, stand composition and fire regime along the transect. At each of the sites along the transect, stands covering the regional spectrum of tree species composition and fire regimes were identified. This was comparatively easy at the Tunguska site where evergreen and Larix forest occurred in approximately equal proportions. Towards the east (Bajkit, Vanavara), stands dominated by evergreen forest 
Table 2. Stand locations, canopy species, stand density and canopy height of the study plots. Picea is a Picea obovata, and Abies is Abies sibirica.

\begin{tabular}{|c|c|c|c|c|c|c|c|c|c|c|}
\hline $\begin{array}{l}\text { Plot } \\
\text { no }\end{array}$ & $\begin{array}{l}\text { Plot } \\
\text { identifier }\end{array}$ & Location & Longitude & Latitude & $\begin{array}{l}\text { Canopy } \\
\text { species }\end{array}$ & $\begin{array}{l}\text { Density } \\
\text { (trees/ha) }\end{array}$ & $\begin{array}{l}\text { Canopy } \\
\text { height } \\
\text { (m) }\end{array}$ & $\begin{array}{l}\text { Age of } \\
\text { main } \\
\text { canopy }\end{array}$ & $\begin{array}{l}\text { No. of fires } \\
\text { incl. stand } \\
\text { replacement }\end{array}$ & $\begin{array}{l}\text { Time } \\
\text { since } \\
\text { last fire }\end{array}$ \\
\hline 1 & VA1-P1 & $\begin{array}{l}\text { Vanavara, } \\
\text { plateau }\end{array}$ & $101^{\circ} 56.025^{\prime}$ & $60^{\circ} 25.014^{\prime}$ & Larix & 973 & 33.5 & 240 & 5 & 160 \\
\hline 2 & VA1-P2 & $\begin{array}{l}\text { Vanavara, } \\
\text { plateau }\end{array}$ & $101^{\circ} 56.049^{\prime}$ & $60^{\circ} 24.970^{\prime}$ & Larix, Picea & 951 & 27.1 & 240 & 3 & 210 \\
\hline 4 & VA2-P1 & $\begin{array}{l}\text { Vanavara, } \\
\text { N-slope }\end{array}$ & $101^{\circ} 59.005^{\prime}$ & $60^{\circ} 20.251^{\prime}$ & $\begin{array}{l}\text { Larix, Alnus, } \\
\text { Pinus sibirica }\end{array}$ & 597 & 30.1 & 170 & 3 & 100 \\
\hline 7 & BK1-P2 & $\begin{array}{l}\text { Bajkit, winter } \\
\text { road, plateau }\end{array}$ & $96^{\circ} 30.089^{\prime}$ & $61^{\circ} 42.586^{\prime}$ & $\begin{array}{l}\text { Larix, Picea, } \\
\text { Abies, } \\
\text { Pinus sibirica }\end{array}$ & 849 & 28.2 & 250 & 3 & 210 \\
\hline 8 & BK2-P1 & $\begin{array}{l}\text { Bajkit-west, } \\
\text { S-slope }\end{array}$ & $96^{\circ} 17.635^{\prime}$ & $61^{\circ} 38.119^{\prime}$ & $\begin{array}{l}\text { Larix, } 3 \\
\text { generations }\end{array}$ & 1304 & 25.8 & 230 & 4 & 140 \\
\hline 9 & TG1-P1 & $\begin{array}{l}\text { Tunguska, } \\
\text { S-slope }\end{array}$ & $95^{\circ} 57.354^{\prime}$ & $61^{\circ} 43.553^{\prime}$ & Larix after fire & 796 & 20.5 & 150 & 3 & 10 \\
\hline 10 & TG2-P1 & $\begin{array}{l}\text { Tunguska, } \\
\text { river bank }\end{array}$ & $95^{\circ} 53.830^{\prime}$ & $61^{\circ} 46.918^{\prime}$ & Picea & 1496 & 28.2 & 120 & 0 & Unknown \\
\hline 14 & TG5-P1 & $\begin{array}{l}\text { Tunguska, } \\
\text { Table Mtn, } \\
\text { E-slope }\end{array}$ & $93^{\circ} 44.809^{\prime}$ & $61^{\circ} 54.495^{\prime}$ & Larix, Picea & 1304 & 30.5 & 250 & 0 & 250 \\
\hline 15 & TG5-P2 & $\begin{array}{l}\text { Tunguska, } \\
\text { Table Mtn, } \\
\text { E-slope }\end{array}$ & $93^{\circ} 44.390^{\prime}$ & $61^{\circ} 54.719^{\prime}$ & $\begin{array}{l}\text { Pinus sibirica, } \\
\text { Abies, Picea }\end{array}$ & 1751 & 29.3 & 255 & 0 & 250 \\
\hline 16 & TG6-P1 & $\begin{array}{l}\text { Tunguska, } \\
\text { N-slope }\end{array}$ & $93^{\circ} 24.893^{\prime}$ & $61^{\circ} 49.711^{\prime}$ & Pinus sibirica & 692 & 31.5 & 330 & 0 & 330 \\
\hline
\end{tabular}

became increasingly rare and identifying them required a prior analysis of remote sensing imagery.

A set of 24 Landsat ETM+ scenes (from path 142 to 147 and from raw 16 to 17) were used to explore and analyze the study area. These satellite images were acquired between 2001 and 2003. For each scene two acquisition dates were selected one during the forest growing season (sum- mer) and the other during winter time when the ground is covered by snow. In addition to Landsat ETM+ data also a summer mosaic image created from the multi-temporal SPOTVGT data (Bartalev et al., 2003) was used. This mosaic is cloud-free and keeps most of the spectral information of the single 10-d composite products. The mosaic available at http://terranorte.iki.rssi.ru provides a comprehensive and 
harmonized view of the forest patterns over all the extension of the study area.

The satellite data, in particular the information contained in the Landsat ETM+ spectral bands number 3, 4 and 5 were combined with forest field data (forest inventory plots and forest description points) that were collected in 2002 during an earlier expedition from Bajkit to Bor and also with data collected along the Yenisei Ridge during three field expeditions in the summer of year 1999 and the spring and summer of year 2000 .

The images acquired during the growing seasons were elaborated to generate forest-type maps. These maps were obtained through a digital supervised classification process based on a "maximum likelihood model". In this classification approach the pixels (satellite data) are assigned to the classes of highest probability that are characterized through the spectral properties assessment of the "training sites" (known forest areas, e.g. forest area with field plots of information points).

The spectral properties differences between the Larix dominated canopies and the coniferous evergreen canopies allow a clear delineation of the current patches of evergreen forests existing within the Larix-dominated region (see Fig. 1).

Based on this survey, areas of evergreen forest surrounded by Larix forest were identified before the main expedition started in 2004. In addition, local forest authorities were consulted. They identified areas which, according to their records, had not been affected by fire. This information was compared with our map derived from satellite data. In this way, we were able to identify clusters of stands covering a wide range in composition and historical fire regime. The evergreen forest patches in the Larix region had variable sizes ranging from a few hectares to square kilometers. Plots representing mature forest were selected randomly within and outside forests containing a large fraction of evergreen conifers, but being within a manageable distance to the river. Bogs, topographic depressions and steep slopes were avoided, such that plots were on gentle slopes and on mineral soils. The soils were classified after a plot had been set.

Table 2 shows that the selected study plots experienced up to seven fire events, including the stand-replacing fire of the main canopy generation (for the method of fire dating, see below). All fires since the stand-replacing event were surface fires, which do not destroy the main canopy. There were sites with a long time since the last fire $(>250 \mathrm{yrs})$ mainly in the mountain range of the Tunguska canyon, due to the low human population density, the dominance of indigenous people, and the fact that Pinus sibirica is used as cash crop for its nuts. Thus, the only site that had had no detectable fire for more than 300 yrs was found in the mountain range.

\section{Methods}

All analyses refer to inventory data that were collected on circular plots with $20 \mathrm{~m}$ radius (in total about 1000 trees). Measurements included stand composition, tree position, tree height and diameter at breast height $(\mathrm{DBH})$ for all trees with a $\mathrm{DBH}>7 \mathrm{~cm}$. Seedlings and saplings were counted on a transect of $10 \mathrm{~m} \times 1 \mathrm{~m}$ starting at the centre of the inventory circle and running west. Soils were investigated using a soil pit to a depth of at least $50 \mathrm{~cm}$. For each plot the topographic variables slope and exposition were recorded. A vegetation survey $(4 \times 4 \mathrm{~m})$ was conducted in the centre of the plot. The organic layer thickness and the depth to the permafrost were determined from five systematically placed soil pits per plot. One deep soil pit was excavated in each of the three study regions and the soil profile described.

Five sample trees of each species were harvested at each site covering the range of DBH, resulting in 293 sample trees which were dated based on stem discs taken at the base and at breast height of each of the harvested trees. In addition, cores of additional 223 trees were taken at breast height.

The fire history was reconstructed using two complementary standard methods: (1) fire scars of harvested trees were dated. Especially important were stem discs of old 'witness' trees which had survived the stand-replacing fire initiating regeneration of the dominant cohort and which also recorded subsequent surface fires. (2) In addition, fire events were inferred from the age distribution of Larix cohorts. This method is based on the knowledge that Larix germinates primarily on bare ground after fire (Nikolov and Halmisaari, 1992; Schulze et al., 1995). Neighboring plots may have experienced different numbers of ground fires as shown for instance by VA1, VA2 and VA3 in Table 2.

For aging and growth measurements, tree-ring width was measured using a dissecting microscope mounted on a table to measure radial displacement (LinTab III,500: Rinntech, Heidelberg, Germany). All tree-ring data were compiled by von Lüpke (2006) and cross-dated with the program COFECHA (Grissino-Mayer, 2001). The age of three old trees was extrapolated based on the age relation of relative growth rates of old trees and the tree diameter. The age difference between the hypocotyl and the breast height was determined for a few sample trees. This difference was relatively small for Larix (15 to $30 \mathrm{yrs}$ ), but it could be higher for evergreen sub-canopy trees (Schulze et al., 2005).

Separately for each species, and based on the distribution of breast height diameter, a range of trees were cut for wood volume determination. The diameter-stem volume relationships were compared with those of a wide range of model trees used for the establishment of generic species-specific biomass functions for central Siberia (C. Wirth and V. Usoltsev, unpublished data). Given that there were no significant differences, the generic biomass functions were used to calculate stand-level biomass for all species by adding the compartment biomasses (root, stem, branches, leaves - 
not reported separately here). Both fitting (for all species and compartments) and prediction was carried out simultaneously using a Monte-Carlo-Markov-Chain (MCMC) algorithm implemented in WinBUGS (Lunn et al., 2000). We used the basic allometric model

$w_{i}=\beta_{0, i} d^{\beta_{1, j}}$

where $w=$ dry weight $(\mathrm{kg})$ and $d=$ diameter at breast-height (cm), $i=$ the individual tree, and $j$ indicates the compartment. We assumed that the data were normally distributed around the mean prediction with a heteroscedastic variance, which was modelled as a power function of the diameter $\left(\sigma_{i}=\beta_{2, i} d^{\beta_{3, j}}\right)$. Mean and variance of plot-level sums of species and compartments were calculated and monitored for 50000 iterations after the MCMC had converged.

Performance of tree species along the transect was compared based on the following five variables reflecting the growth and stature of the regenerating and mature trees which were harvested or cored during this expedition: (1) relative radial increment at $\mathrm{DBH}$ of $30 \mathrm{~cm}$ $\left(\mathrm{RI}_{30}\right)=$ instantaneous growth rate of mature trees; (2) DBH at an age $200 \mathrm{yrs}\left(D_{200}\right)=$ lifetime growth rate of mature trees; (3) relative radial increment of young trees at $20 \%$ of light $\left(\mathrm{RI}_{\mathrm{y}}\right)=$ regeneration growth in understorey light conditions, (4) height at DBH $15 \mathrm{~cm}\left(H_{15}\right)=$ slenderness of young trees; (5) height at DBH $40 \mathrm{~cm}\left(H_{40}\right)=$ slenderness of old trees. To facilitate the comparison all estimates are given in the form of mean predictions of fitted functions at a standard size, age or light level, respectively. The functions were fitted with MCMC in WinBUGS as above. The mean predictions and their inter-specific differences per site were monitored. Differences whose $95 \%$ credible intervals exclude zero are reported as significant. The underlying data and functions for the performance variables are the following: $\mathrm{RI}_{30}$ : the relative radial increment (RI) measured on stem discs or additional tree cores $(n=259)$ was regressed against DBH for tree $j$ of species $i$ at site $k$ using

$\mathrm{RI}_{i j k}=\beta_{0, i k}+\beta_{1, i k} \mathrm{DBH}_{i j k}$.

The species- and site-specific parameters $\beta_{0, i}$ and $\beta_{1, i}$, intercept and slope, respectively, were used to predict RI of a mature tree with a DBH of $30 \mathrm{~cm}$ which corresponds to performance variable Eq. (1), $\mathrm{RI}_{30}$.

$D_{200}$ : using the dated age of the same set of harvested trees and tree cores $(n=259)$, DBH was regressed against age $A$ for tree $j$ of species $i$ at site $k$ using

$\mathrm{DBH}_{i j k}=\beta_{0, i k}+\beta_{1, i k} A_{i j k}$.

to give the predicted DBH of species $j$ at site $k$ at an age of $200 \mathrm{yrs}$, performance variable Eq. (2), $D_{200}$.

$\mathrm{RI}_{\mathrm{y}}$ : relative radial increment of young trees was estimated based on radial increments measured on randomly selected individuals $(n=100)$ of the understorey regeneration ranging in DBH from 1 to $6 \mathrm{~cm}$. Sample sizes ranged from 5 to 23 per species depending on their availability in the plot. Radial increment was measured along four radii at a height of $10 \mathrm{~cm}$ above ground. $\mathrm{RI}_{\mathrm{y}}$ was calculated as the mean ring width of the years 1999 to 2003 divided by the mean radius. Since growth rates of understorey regeneration are highly sensitive to light conditions, hemispherical canopy pictures were taken on top of each harvested individual and the percentage of available light relative to incident light above the canopy $(L)$ was calculated using the software GLA (Canham, 1988). A linear model with subscripts in Eq. (1)

$\mathrm{RI}_{\mathrm{y}, i j}=\beta_{0, i}+\beta_{1, i} L_{i j}$,

was used for testing differences in $\mathrm{RI}_{\mathrm{y}}$. Prior to the analysis, $L$ was normalized by subtracting the mean value of $L$. Light and light-species interactions (separate $\beta_{1}^{\prime} s$ ) were included in the overall model if significant. Predictions of $\mathrm{RI}_{\mathrm{y}}$ at a light level of $20 \%$ (representing the mean understory light conditions) were used as a basis of comparison.

$H_{15}$ and $H_{40}$ : based on all inventoried plot trees with a DBH $>7 \mathrm{~cm}(n=424)$ tree height $H$ was regressed against DBH using the equation

$H_{i j k}=1.3+\beta_{0, j k}\left(1-e^{-\frac{\beta_{1, j k}}{\beta_{0, j k}} \mathrm{DBH}_{i j k}}\right)$,

where $\beta_{0}$ is the asymptote and $\beta_{1}$ the initial slope and the subscripts are defined as in Eq. (1). The intercept of $1.3 \mathrm{~m}$ represents the height at which the diameters were measured. The parameters were estimated for the three most common species (Larix gmelinii, Picea obovata and Pinus sibirica) only. The predicted heights at a DBH of $15 \mathrm{~cm}$ and $40 \mathrm{~cm}$ correspond to performance variables Eq. (4) and (5).

\section{Statistical analysis at the stand level}

We used general linear models and backward selection based on the Akaike Information Criterion (step procedure in $R$ ) to explore the relative importance of different factors (climate, topography, fire regime, soil condition) on stand composition, biomass and forest floor carbon stocks. For the dependent variables original values were used for biomass, carbon stocks and abundances. Stand composition (i.e. percentage basal area of dark taiga species versus Larix) was arcsinetransformed to ensure normality. To avoid over-fitting in face of the limited number of stands $(n=16)$ we restricted the number of predictors in the full model to seven (including the intercept). The correlation matrix of stand-level predictors (Table 3) shows a strong correlation of annual precipitation and temperature with longitude. However, given the small number of weather stations and their inherent uncertainties, we used only the latter as predictor representing the continental gradient along the transect. The time since the last fire was used as the predictor characterizing the fire regime. The number of fires during stand development had a positive correlation $(r=0.64)$ with longitude and an associated negative 
Table 3. Correlation matrix of stand-level predictors and compositional attributes. Long $=$ longitude, distriver $=$ distance to river, precip $=$ precipitation, mat $=$ Mean annual temperature, age $=$ stand age, $t$ tsf $=$ time-since-fire, nofire $=$ number of fires during stand development, mri $=$ mean fire return interval calculated as "age $/(1+$ nofire $)$ ", water $=$ ordinal water index from 1 very dry to 5 very wet, slomax $=$ maximum slope, soild = depth of soil until bed rock, alt = active-layer depth, olt = organic layer depth, ba.dt = basal area of dark taiga species $($ Picea, Abies, Pinus sibirica), ba.brl = basal area of broadleaved species (Betula, Populus, Alnus), ba.lar $=$ basal area of Larix, ba.tot $=$ total basal area, bar.dt $=$ percentage basal area of dark taiga species, bar.brl = percentage basal area of broadleaved species, bar.lar $=$ percentage basal area of Larix.

\begin{tabular}{|c|c|c|c|c|c|c|c|c|c|c|c|c|c|c|c|c|c|c|c|}
\hline & distriv & precip & mat & age & tsf & nofire & mri & water & slomax & soild & alt & olt & ba.dt & ba.brl & ba.lar & ba.tot & bar.dt & bar.brl & bar.lar \\
\hline long & 0.30 & -0.94 & -0.77 & -0.25 & -0.12 & 0.56 & -0.61 & -0.22 & -0.52 & -0.21 & -0.29 & 0.10 & -0.51 & 0.23 & 0.71 & -0.07 & -0.55 & 0.31 & 0.50 \\
\hline distriver & & -0.44 & -0.60 & 0.14 & -0.02 & 0.44 & -0.29 & -0.05 & -0.41 & -0.29 & -0.50 & 0.50 & -0.02 & 0.19 & 0.09 & 0.07 & 0.05 & 0.22 & -0.08 \\
\hline precip & & & 0.92 & 0.09 & 0.02 & -0.56 & 0.48 & 0.31 & 0.65 & 0.25 & 0.45 & -0.25 & 0.40 & -0.30 & -0.69 & -0.07 & 0.46 & -0.37 & -0.40 \\
\hline mat & & & & 0.05 & 0.07 & -0.66 & 0.52 & 0.29 & 0.69 & 0.23 & 0.52 & -0.35 & 0.36 & -0.30 & -0.59 & -0.03 & 0.37 & -0.36 & -0.32 \\
\hline age & & & & & 0.01 & -0.06 & 0.47 & -0.43 & 0.34 & -0.37 & -0.07 & 0.24 & 0.29 & 0.13 & -0.16 & 0.27 & 0.31 & 0.11 & -0.32 \\
\hline tsf & & & & & & -0.69 & 0.62 & 0.12 & -0.38 & 0.16 & -0.34 & -0.14 & 0.77 & 0.12 & -0.39 & 0.73 & 0.69 & 0.11 & -0.72 \\
\hline nofire & & & & & & & -0.84 & -0.14 & -0.17 & -0.34 & -0.22 & 0.30 & -0.71 & 0.10 & 0.60 & -0.46 & -0.64 & 0.14 & 0.63 \\
\hline mri & & & & & & & & -0.02 & 0.12 & 0.18 & 0.00 & -0.04 & 0.76 & -0.13 & -0.52 & 0.59 & 0.65 & -0.16 & -0.63 \\
\hline water & & & & & & & & & -0.23 & 0.35 & -0.30 & 0.38 & 0.13 & -0.13 & -0.42 & -0.19 & 0.19 & -0.11 & -0.17 \\
\hline slomax & & & & & & & & & & -0.16 & 0.70 & -0.34 & -0.01 & 0.04 & -0.22 & -0.21 & 0.05 & -0.08 & -0.03 \\
\hline Soild & & & & & & & & & & & 0.31 & -0.24 & 0.19 & -0.17 & -0.29 & 0.01 & 0.26 & -0.22 & -0.24 \\
\hline Alt & & & & & & & & & & & & -0.63 & -0.28 & 0.03 & 0.02 & -0.36 & -0.19 & -0.08 & 0.20 \\
\hline Olt & & & & & & & & & & & & & -0.05 & 0.21 & 0.07 & 0.00 & -0.10 & 0.19 & 0.09 \\
\hline ba.dt & & & & & & & & & & & & & & -0.14 & -0.67 & 0.78 & 0.93 & -0.21 & -0.91 \\
\hline ba.brl & & & & & & & & & & & & & & & 0.11 & -0.01 & -0.06 & 0.92 & -0.07 \\
\hline ba.lar & & & & & & & & & & & & & & & & -0.07 & -0.79 & 0.02 & 0.79 \\
\hline ba.tot & & & & & & & & & & & & & & & & & 0.61 & -0.18 & -0.58 \\
\hline bar.dt & & & & & & & & & & & & & & & & & & -0.11 & -0.99 \\
\hline bar.brl & & & & & & & & & & & & & & & & & & & -0.04 \\
\hline
\end{tabular}

correlation $(r=-0.63)$ with precipitation. Even though the relation is significant, it explains only about $40 \%$ of the variation. Thus, there are other factors, which were not quantified in this study, such as human activities. Edaphic site conditions were represented by the active-layer depth at the time of the measurement, the slope, and an ordinal hydrology index ranging from $1=$ very dry to $5=$ very wet. Finally, we introduced the distance from the river as a predictor which we believe to reflect the differences in local climate due to the proximity of the water body as well as edaphic differences. All predictor variables were standardized to a mean of zero and standard deviation of one. Therefore the coefficients as listed in Table 3 reflect the relative importance of the predictors within the models. The intercept represents the value at the mean of all predictors. Dependent variables given in units of percentage were arcsine-transformed prior to the analysis. The selection procedure based on AIC may lead to models with marginally non-significant predictors.

The original data are available at: www.bgc-jena.mpg.de/ bgc-processes/publdata/Tunguska.pdf and www.bgc-jena. mpg.de/bgc-processes/publdata/Tunguska_vonLuepke.pdf.

\section{Results}

\subsection{Tree growth}

The annual increments of the basal area of Larix trees representing different age classes did not show any climate related trend over the past 350 yrs (Fig. 2). Older trees were growing faster than younger trees. Trees which are presently 150 to 200 yrs old grow as fast as $300 \mathrm{yrs}$ old trees did when they were younger. Growth "dips" and "humps" are related to fire events where surviving trees exhibit larger growth rates until the regenerating forest becomes competitive for water and nutrients. There was no sign of an age-related decline in growth of individual trees, even if repeated surface fires occurred and fire scars were present at the stem base.

\subsection{Fire regime and stand structure}

The dating of fire events is crucial in the present study. The timing of fires was determined from the tree-ring analysis of cohorts of Larix differing in age (Fig. 3). Fires were numbered starting from stand-replacing fires of the present canopy (fire event 1). Tree rings of survivors of the last stand-replacing fire (fire event -1 ) were the best indicator for 


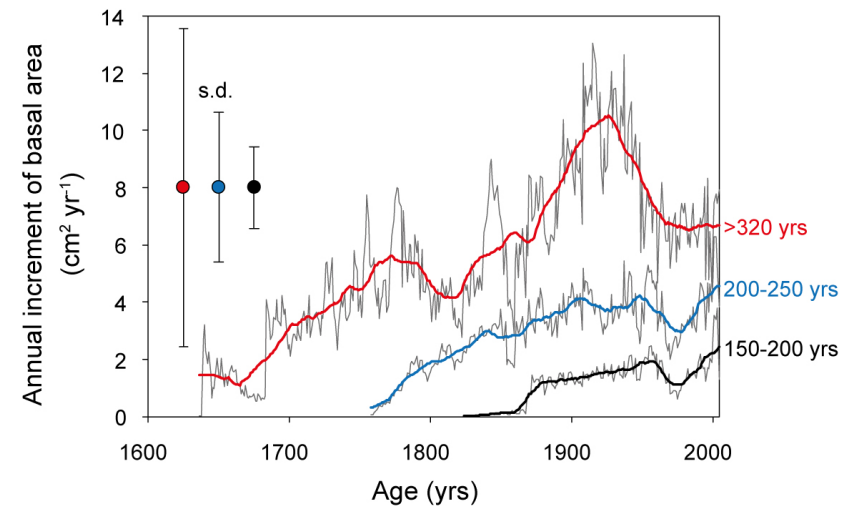

Fig. 2. Annual increment of trees as related to time before present for tree individuals older than $320 \mathrm{yrs}(n=9)$, of individuals between 200 and $250 \mathrm{yrs}(n=29)$, and of individuals between 150 and 200 yrs $(n=8)$. Depicted are averages of annual rates (thin black lines) and a smoothed line of running average over about $10 \mathrm{yrs}$, depending on the number of samples (thick red line for $>320 \mathrm{yrs}$, blue line for 200 to $250 \mathrm{yrs}$ and black line for 150 to $200 \mathrm{yrs}$ ).

dating the stand-replacing event (event 1) using tree rings at fire scars on stem discs of harvested trees as a distinct marker.

At Vanavara (Fig. 3a) plot VA2 may serve as an example for a stand replacing fire $260 \mathrm{yrs}$ ago (fire event 1 ) which was survived by a tree that established after a fire $350 \mathrm{yrs}$ ago (fire event -1 ). The stand replacing fire event 1 was followed by ground fires initiating regeneration (fire events 2, 3 and 4). Few Picea and Pinus sibirica trees survived the fire event 4. The regeneration of fire event 4 has not yet reached breast height.

Most inventory plots contained populations of dark taiga species that were not even-aged (Fig. $3 \mathrm{~b}$ and c). Thus, some individuals of dark taiga species survive ground fires, depending on the patchiness of the regeneration. The site which experienced a single fire event about $250 \mathrm{yrs}$ ago (Fig. 3d) contained only a single Larix tree as a remnant, and an understory of dark taiga species that were not even-aged.

Ground fires may follow a stand-replacing fire (Fig. 3b) as soon as Larix reached a thicket stage, which is vulnerable to fire. Only the tallest trees of a thicket survive. Thus, for Larix, surface fires act as a thinning agent. Fire may even enhance growth of the survivors.

Pinus sibirica regenerated together with Larix after fire near the Yenisei Ridge (Fig. 3d). Pinus sibirica cones are distributed by the Siberian Jay, which prefers open habitats to bury cones. Thus, Pinus siberica is not a typical latesuccessional species but participates in the early succession. Abies and Picea follow with a delay of about $50 \mathrm{yrs}$.

On average, stand-replacing fires occurred about every $229 \pm 52 \mathrm{yrs}$, time since the last fire was $147 \pm 99 \mathrm{yrs}$, and mean fire return frequency was $100 \pm 92$ yrs. These fire intervals may be biased towards longer periods compared to a regional average, due to our selection of old-growth stands.
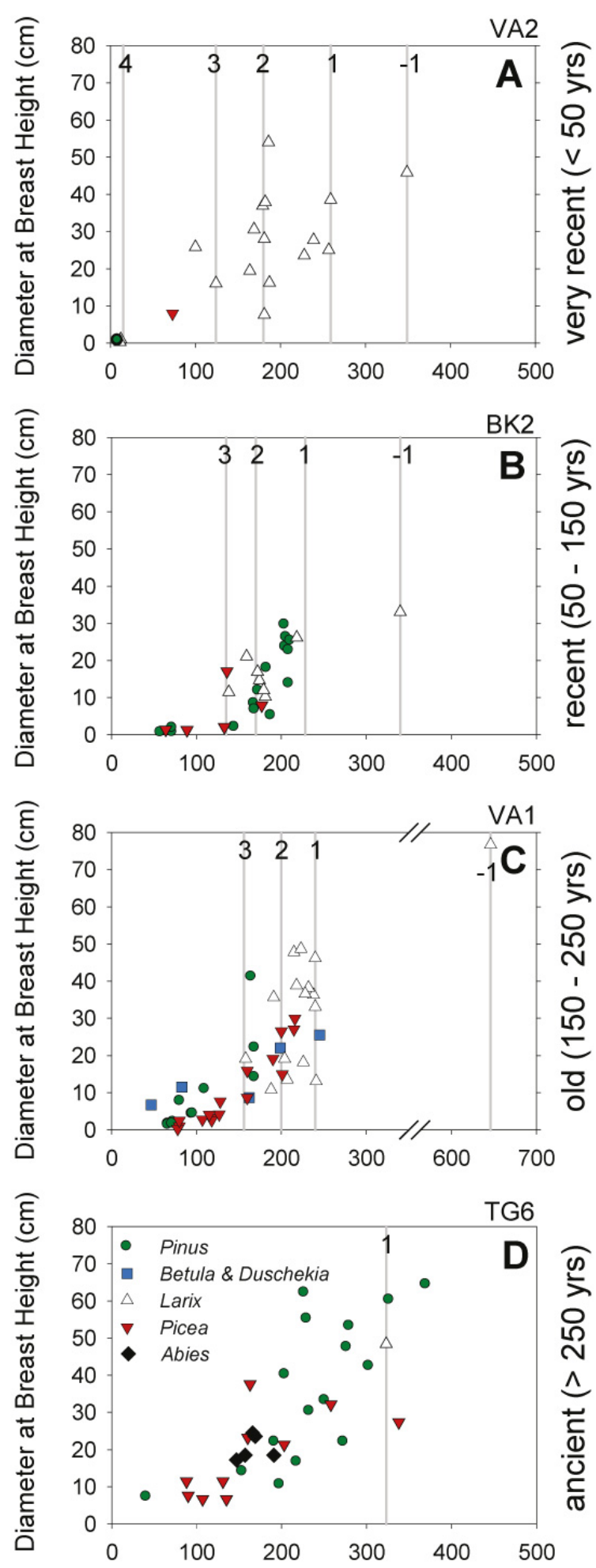

Age [yrs]

Fig. 3. Diameter at breast height as related to tree age along the Tunguska transect. 

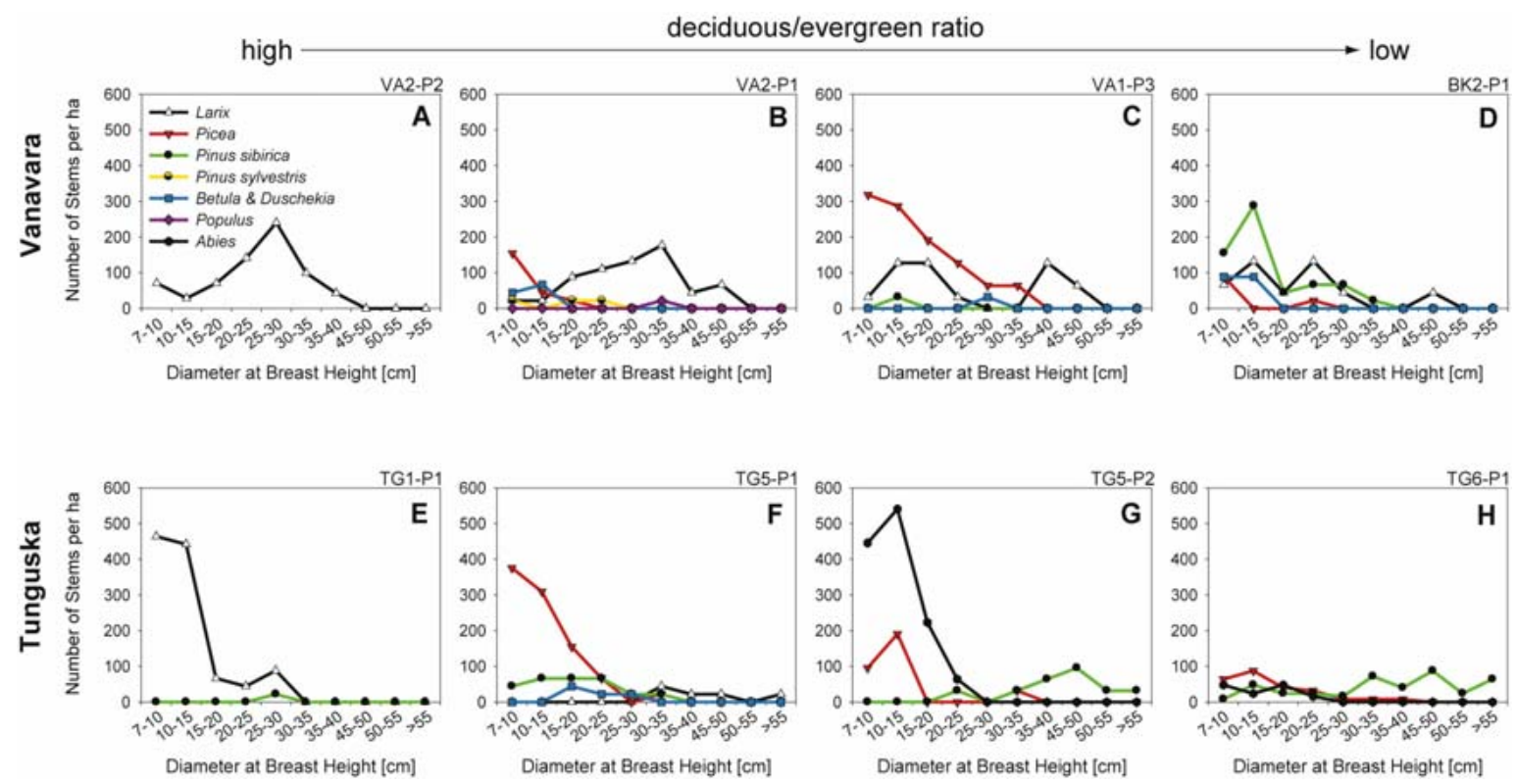

Fig. 4. Stand density (number of stems per area) as related to diameter at breast height of selected plots representing an increasing ratio of deciduous to evergreen stems for the Vanavara-Bajkit region (A to $\mathbf{D})$ and the Tunguska canyon (E to $\mathbf{H})$.
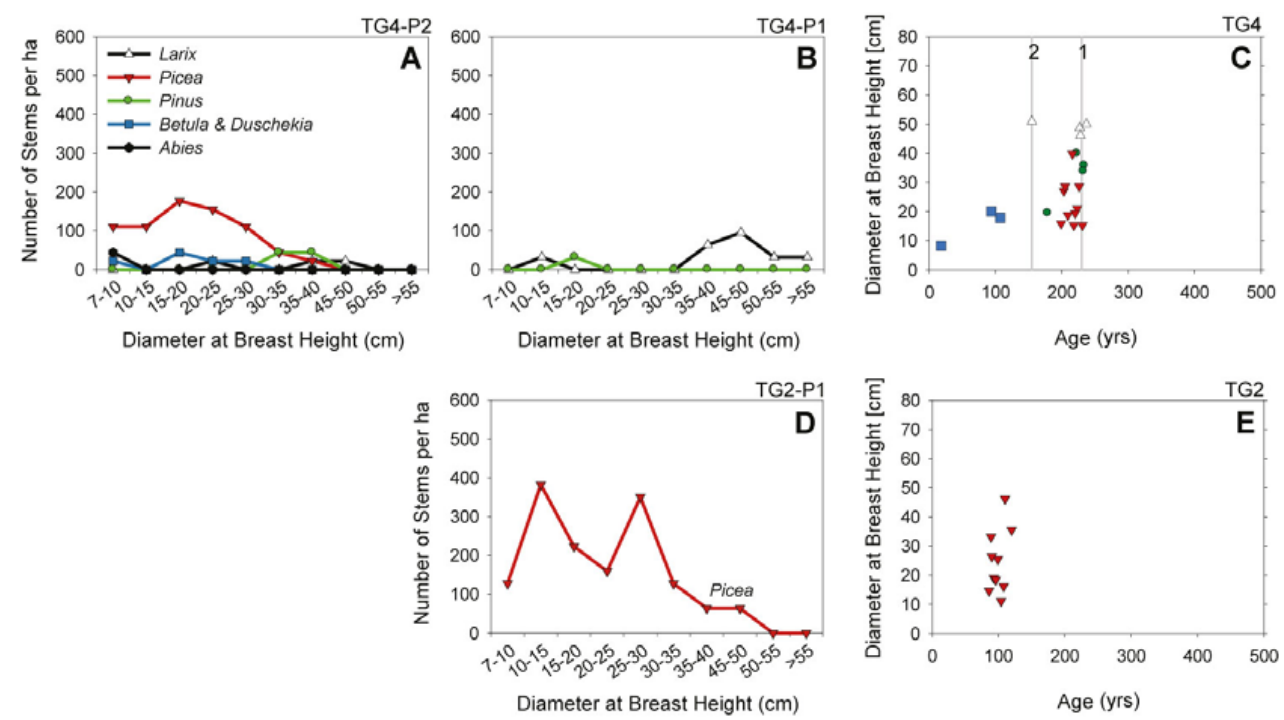

Fig. 5. Diameter at breast height of tree species growing on adjacent sites without (A) and with (B) a recent surface fire, and the relation between diameter at breast height and tree age $(\mathbf{C})$, and density of trees as related to breast height diameter (D) and age (E) in a pure stand of Picea obovata which regenerated on alluvial loam. Symbols are explained in (A).

Irrespective of the age of the last surface fire, tree diameters of the sample trees increased exponentially with age (Fig. 3). Largest breast height diameter reached 70 to $80 \mathrm{~cm}$.

Fire frequency and the time elapsed since the last surface fire determine species composition and stand density (Fig. 4). Surface fires (Fig. 4a, e) generally eradicated the dark taiga species and thin the main canopy. Following a surface fire $(<50 \mathrm{yrs}$ of elapsed time) the stand was characterized by a very dense young population of Larix, which may become thinned in a repeated surface fire. Several "waves" of Larix populations resulted from repeated surface-fire events (Fig. 4c, d). With increasing time elapsed since the latest surface fire (old surface-fires), Picea became a sub-dominant species while Larix persisted with few canopy species and lacking regeneration (Fig. 4g). With more than 250 yrs since the last surface fires the forest was dominated by Pinus sibirica (Fig. 4h). Picea regenerated as ground-vegetation. 

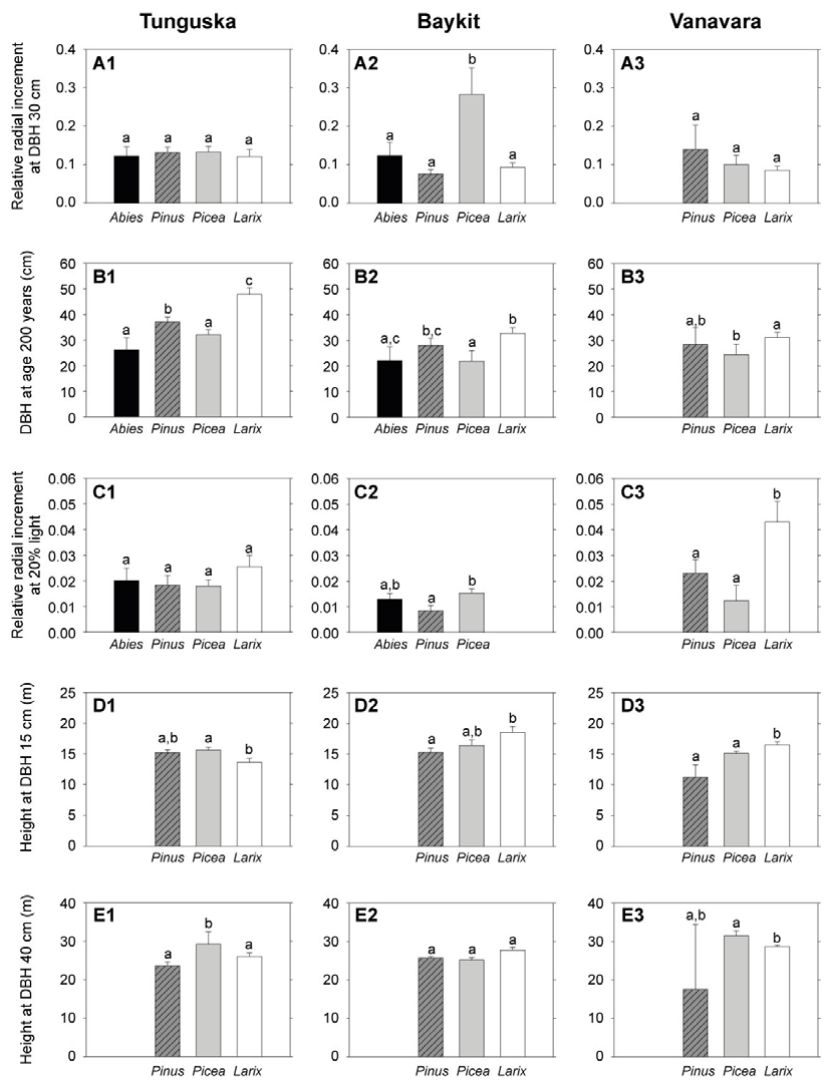

Fig. 6. Relative radial increment, $\mathrm{DBH}$ at age of $200 \mathrm{yrs}$, relative radial increment at $20 \%$ light, height at DBH $15 \mathrm{~cm}$, and height at DBH $40 \mathrm{~cm}$ for Abies, Pinus, Picea and Larix at the Tunguska, the Bajkit and the Vanavara sites. Different small letters indicate significant differences between columns.

The devastating effects of fire on dark taiga species and on accompanying deciduous broadleaved species, such as $B e$ tula and the shrub-like Duschekia (Alnus) fruticosa (Rupr.) Pouzar, became obvious from two neighboring sites, one unburnt (Fig. 5a), the other recently burnt (Fig. 5b). At the unburnt site Betula and Duschekia formed a thicket with stems below $7 \mathrm{~cm}$ DBH underneath a Larix canopy with 35 to $50 \mathrm{~cm} \mathrm{DBH.} \mathrm{Pinus} \mathrm{sibirica} \mathrm{formed} \mathrm{a} \mathrm{second} \mathrm{tree} \mathrm{layer}$ (30 to $40 \mathrm{~cm} \mathrm{DBH)} \mathrm{followed} \mathrm{by} \mathrm{a} \mathrm{continuous} \mathrm{regeneration}$ of Picea. Abies was present at a lower density at the unburnt site. After fire (Fig. 5b) only the Larix canopy and few Pinus sibirica individuals remained. At this site the standreplacing fire had occurred about 220 yrs ago with regeneration of Larix and Pinus sibirica and a delayed regeneration of Picea (Fig. 5c). A surface fire (180 yrs ago) initiated a second cohort of Larix. The Duschekia thicket was of a lower age (100 yrs, Fig. $5 \mathrm{c})$, but the rootstocks of the coppice-like bushes may be older. Duschekia will regenerate from rootstocks. Larix regeneration was still below $7 \mathrm{~cm}$ DBH and thus not apparent in Fig. 5.
A special situation exists on alluvial loams near the river, where Picea may form monotypic stands (Fig. 5d, c). In this case only Picea regenerated on the fresh alluvial material. Although the size distribution suggested several cohorts of Picea, the tree age-distribution (Fig. 5e) indicated that this was a single flood event. It remained unclear, why Larix did not germinate on the fresh alluvial material (Eutric Fluvisol).

\subsection{Stature and growth performance along the transect}

Species differences in relative radial increment of mature trees, $\mathrm{RI}_{30}$, were generally negligible within sites and hardly varied along the transect (Fig. 6a). There was a slight tendency of reduced growth of Larix towards the east, and no consistent longitudinal trend in any of the evergreen conifers. $D_{200}$ - a proxy for the lifetime growth rate - showed a consistent pattern within sites (Fig. 6b). At the Tugunska site Larix reached the largest DBH within $200 \mathrm{yrs}$, followed by Pinus. Abies and Picea show the lowest values. $D_{200}$ generally decreased from Tunguska to Bajkit, but there were no significant differences between Bajkit and Vanavara for either species. The relative radial increment of understorey trees, $\mathrm{RI}_{\mathrm{y}}$, was similar for all tree species in Tunguska (Fig. 6c), but increased for Larix and decreased for Picea and Pinus towards the east. As a consequence, at Vanavara, $\mathrm{RI}_{\mathrm{y}}$ of Larix was more than twice that of Picea and Pinus. There were significant changes in stem form along the transect. In the west at Tunguska the height at a DBH of $15 \mathrm{~cm}, H_{15}$, was lower in Larix than in Picea and Pinus indicating a more slender stem form in the evergreen conifers (Fig. 6d) which may be caused by competition for light in denser stands of the western sites independent of species rather than being an effect of climate.

Towards the east, $H_{15}$ of Picea remained constant, increased for Larix and decreased for Pinus. The apparent regional differences in $H_{15}$ appeared to be a result of competition in dense or fire-thinned regrowth. Solitary grown trees generally had reduced $H_{15}$.For the shape of large, mature trees, as quantified by $H_{40}$, the picture was comparable (Fig. 6e). Larix grew taller towards the east $(29 \mathrm{~m}$ in Vanavara versus $26 \mathrm{~m}$ in Tunguska) and Pinus grew stouter, while no consistent pattern was visible for Picea. This again could also be the result of competition during regeneration. In summary, indicators of growth performance of mature trees $\left(\mathrm{RI}_{30}, D_{200}\right)$ did not show dramatic changes along the longitudinal transect, while a differentiation in juvenile growth was visible, resulting from possible regional effects and from competition during regrowth.

\subsection{Controls on species composition and carbon stocks}

Total aboveground biomass varied between about 50 and $130 \mathrm{t} \mathrm{Cha}^{-1}$ in mature stands irrespective of the species composition (Table 4). Aboveground biomass carbon (model 3) was most strongly controlled by the time elapsed since the 

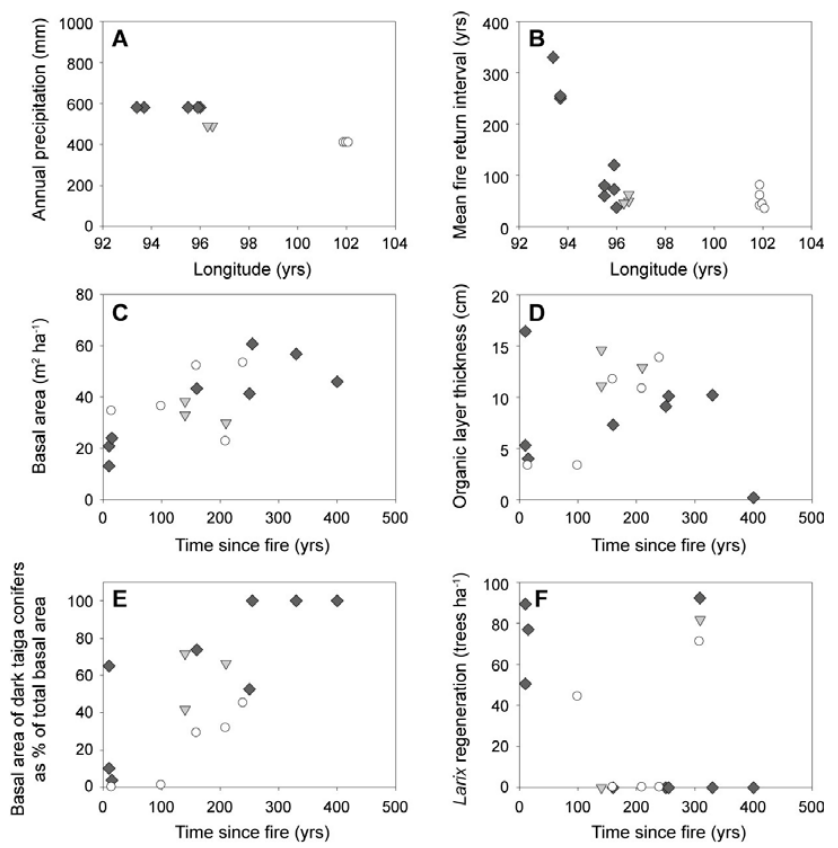

Fig. 7. Annual precipitation (A) and mean fire return interval (B) as related to longitude, basal area (C) and organic-layer thickness (D), and relative fraction of basal area of dark taiga conifers (E) and Larix regeneration $(\mathbf{F})$ as related to time-since-fire.

last surface fire (TSF) as reflected by its high standardized regression coefficient (2.17) (Table 5). Additional factors determining biomass were in decreasing order of influence, the site hydrology (significant with $p<0.05$ ), active-layer thickness and the distance to the river - all of them with a negative sign. Time-since-fire was consistently the most important predictor for all dependent variables related to the species composition (models 4 and 5: biomass fractions for adults $>7 \mathrm{~cm} \mathrm{DBH}$ and models 6 and 7: absolute abundances for saplings).

There was a strong influence of water availability on the organic layer thickness (model 1, Table 5). Beyond that there was positive influence of the distance to the river and of timesince-fire as well as a negative influence of the active-layer thickness. The overall model 1 explained $90 \%$ of the variation. In contrast, the carbon content in the organic layer (model 2) was neither related to water availability nor to time-since-fire, but only to the distance from the river and the active-layer depth. The site TG2-P1, which was positioned on a river island, was removed from the organic layer analysis because regular spring floods had removed the forest floor material entirely.

When relating fire events to climate, it appears that while precipitation decreased from $600 \mathrm{~mm}$ to $400 \mathrm{~mm}$ from west to east (Fig. 7a), the mean fire return interval decreased also from $300 \mathrm{yrs}$ to about $50 \mathrm{yrs}$ (Fig. 7b). Associated with an increase in the time-since-fire was an increase in stand basal area (Fig. 7c), while there was no consistent change

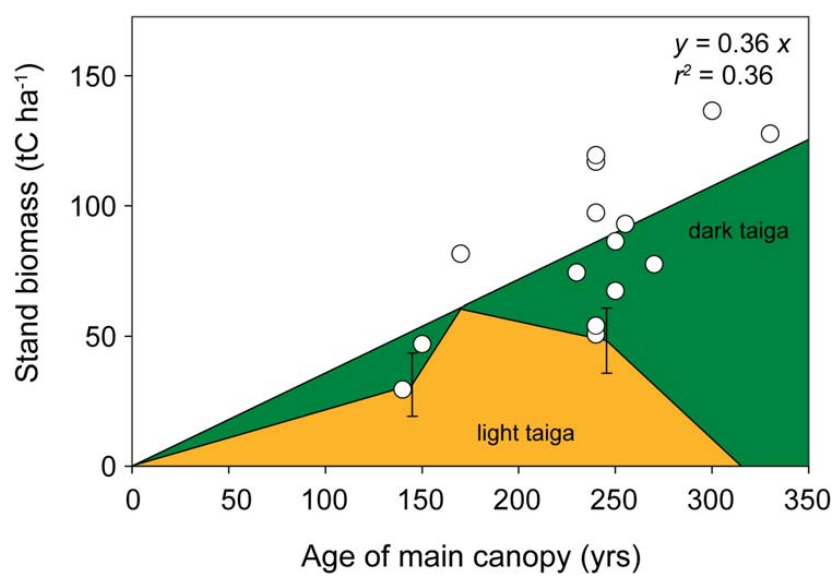

Fig. 8. Stem volume per unit area as related to stand age. The shaded area indicates the proportion of light and dark taiga species on total stem biomass. Dark taiga species may also contribute a significant fraction in young stands until the first surface fire eradicates these individuals. Only a next generation can become dominant, if there is no further fire.

in organic-layer thickness (Fig. 7d). However, the fraction of dark taiga species (Picea obovata, Abies sibirica, Pinus sibirica) increased with time-since-fire and decreased for Larix (Fig. 7e). In addition, species composition was influenced by longitude, which we consider a proxy for an increasingly continental climate. At a given time-since-fire, fractional biomass of adult dark taiga species decreased towards the east, while it increased for Larix. In Vanavara the maximum percentage biomass of the dark taiga species reached $37 \%$, whereas in Tunguska it reached $100 \%$ in three plots. The models 4 and 5 for adult species composition with respect to the fraction of dark taiga conifers and Larix, respectively, explained about $75 \%$ of the variance. The dependence of Larix sapling abundance on time-since-fire was strongly nonlinear. Larix saplings were virtually absent in stands older than 100 yrs (Fig. 7f).

\subsection{Integrated stand growth and biomass during a fire cycle}

In a comparison of all sites of the Podkamenaya Tunguska basin (Fig. 8) stand volume increased linearly over time with a rate of about $0.36 \mathrm{tCha}^{-1} \mathrm{yr}^{-1}$ despite the different fire histories and dramatic changes in species composition. Stem volume reached about $130 \mathrm{tCha}^{-1} 350 \mathrm{yrs}$ after a stand-replacing fire. In the first phase of growth (up to 100 yrs) Picea co-dominated with Larix, but due to the repeated surface fires, 150 to $200 \mathrm{yrs}$-old stands were almost pure Larix stands. 200 yrs after a stand-replacing fire the contribution of Larix to total biomass decreases if there were no additional surface fire which would promote new Larix regeneration. Larix disappears at the plot scale if there was no surface fire for $350 \mathrm{yrs}$. Pinus sibirica and Picea became 
Table 4. Biomass carbon stocks including roots $\left[\mathrm{t} \mathrm{Cha}^{-1}\right]$ in the investigated plots. Dark taiga conifers include Picea obovata, Abies sibirica, and Pinus sibirica, light-taiga conifers include Larix sp. and Pinus sylvestris (see *); broadleaved trees include Betula sp., Populus tremula, and Duschekia fruticosa. $\mathrm{sd}=$ standard deviation of biomass prediction.

\begin{tabular}{|c|c|c|c|c|c|c|c|c|}
\hline \multirow[t]{2}{*}[\mathrm{tCha}^{-1}]{} & \multicolumn{2}{|c|}{$\begin{array}{c}\text { Dark Taiga } \\
\text { conifers }\end{array}$} & \multicolumn{2}{|c|}{$\begin{array}{c}\text { Light Taiga } \\
\text { conifers }\end{array}$} & \multicolumn{2}{|c|}{ Broadleaved } & \multirow{2}{*}{$\frac{\text { Total }}{\text { mean }}$} & \multirow{2}{*}{$\begin{array}{r}\text { Total } \\
\text { sd }\end{array}$} \\
\hline & mean & sd & mean & sd & mean & $\mathrm{sd}$ & & \\
\hline VA1-P1 & 28.94 & 0.78 & 93.00 & 2.72 & 2.27 & 0.04 & 124.20 & 2.82 \\
\hline VA1-P2* & 11.66 & 0.42 & 29.29 & 0.72 & 8.76 & 0.18 & 49.72 & 0.85 \\
\hline VA1-P3* & 44.42 & 1.45 & 70.35 & 1.98 & 4.78 & 0.12 & 119.55 & 2.44 \\
\hline VA2-P1 & 0.53 & 0.03 & 85.02 & 2.03 & 1.04 & 0.02 & 86.60 & 2.03 \\
\hline VA2-P2 & - & - & 78.80 & 1.67 & - & - & 78.80 & 1.67 \\
\hline BK1-P1 & 52.47 & 1.20 & 23.22 & 0.59 & 4.04 & 0.10 & 79.70 & 1.34 \\
\hline BK1-P2 & 35.24 & 0.74 & 21.27 & 0.62 & 4.97 & 0.10 & 61.45 & 0.96 \\
\hline BK2-P1 & 23.44 & 0.85 & 40.21 & 0.87 & 3.44 & 0.06 & 67.10 & 1.22 \\
\hline TG1-P1 & 2.53 & 0.09 & 22.85 & 0.34 & - & - & 25.38 & 0.35 \\
\hline TG2-P1 & 96.40 & 3.36 & - & - & - & - & 96.40 & 3.36 \\
\hline TG3-P1 & 24.85 & 0.79 & 14.36 & 0.22 & - & - & 39.21 & 0.82 \\
\hline TG4-P1 & 1.55 & 0.07 & 61.45 & 1.91 & - & - & 63.00 & 1.92 \\
\hline TG4-P2 & 64.45 & 1.66 & 20.39 & 0.62 & 10.17 & 0.23 & 95.00 & 1.78 \\
\hline TG5-P1 & 37.07 & 0.98 & 47.32 & 1.67 & 7.70 & 0.18 & 92.10 & 1.94 \\
\hline TG5-P2 & 27.33 & 4.11 & - & - & - & - & 127.35 & 4.11 \\
\hline
\end{tabular}

* These are the only two stand containing the light taiga species Pinus sylvestris as a minor component next to Larix $^{(4.6}$ and $5.4 \mathrm{tC}$ ha $\left.{ }^{-1}\right)$.

Table 5. Best candidate models for selected variables representing stand composition, biomass and organic layer carbon; standard error of estimates in brackets. Because all predictors were z-transformed prior to analysis the magnitude of the coefficients reflects the relative importance of the respective variables. Significance indicators: $* p<0.05, * * p<0.01$. Indicators for overall model significance based on the $F$-statistic are shown together with $R_{\mathrm{a}}^{2}$.

\begin{tabular}{|c|c|c|c|c|c|c|c|c|c|c|c|}
\hline $\begin{array}{l}\text { Model } \\
\text { number }\end{array}$ & Parameter & Intercept & $\begin{array}{l}\text { Longitude } \\
\left({ }^{\circ}\right)\end{array}$ & $\begin{array}{l}\text { Distance } \\
\text { to River (m) }\end{array}$ & $\begin{array}{l}\text { Active Layer } \\
\text { Depth }(\mathrm{cm})\end{array}$ & $\begin{array}{l}\text { Time since last } \\
\text { Fire (years) }\end{array}$ & $\begin{array}{l}\text { Slope } \\
\left({ }^{\circ}\right)\end{array}$ & $\begin{array}{l}\text { Hydrology } \\
\text { Index }\end{array}$ & Adjusted $R_{\mathrm{a}}^{2}$ & $\begin{array}{l}\text { Residual } \\
\text { Standard } \\
\text { Error }\end{array}$ & $\begin{array}{l}\text { Degree } \\
\text { freedom }\end{array}$ \\
\hline 1 & $\begin{array}{l}\text { Aboveground } \\
\text { tree biomass } \\
\left(\mathrm{kg} \mathrm{C} \mathrm{m}^{-2}\right)\end{array}$ & $\begin{array}{l}8.36^{* *} \\
(0.56)\end{array}$ & - & $\begin{array}{l}-0.86 \\
(0.67)\end{array}$ & $-0.92(0.69)$ & $2.17 * *(0.61)$ & - & $\begin{array}{l}-1.41^{*} \\
(0.61)\end{array}$ & $0.49(* *)$ & 2.27 & 11 \\
\hline 2 & $\begin{array}{l}\text { Biomass of dark } \\
\text { taiga species } \\
(\%)^{2}\end{array}$ & $\begin{array}{l}42.8^{* *} \\
(3.73)\end{array}$ & $\begin{array}{l}-13.7 * * \\
(3.97)\end{array}$ & - & - & $18.5^{* *}(3.97)$ & - & - & $0.74(* *)$ & 14.9 & 13 \\
\hline 3 & $\begin{array}{l}\text { Biomass of } \\
\text { Larix }(\%)^{2}\end{array}$ & $\begin{array}{l}44.7 * * \\
(3.5)\end{array}$ & $\begin{array}{l}10.9^{*} \\
(4.87)\end{array}$ & - & $8.36(5.29)$ & $-19.9 * *(4.34)$ & $\begin{array}{l}-8.3 \\
(6.37)\end{array}$ & - & $0.76(* *)$ & 14.0 & 11 \\
\hline 4 & $\begin{array}{l}\text { Dark taiga } \\
\text { regeneneration } \\
\text { (trees } \mathrm{ha}^{-1} \text { ) }\end{array}$ & $\begin{array}{l}896 * * \\
(220)\end{array}$ & $\begin{array}{l}813^{*} \\
(319)\end{array}$ & - & - & $758 *(267)$ & - & 306 (254) & 0.38 & 805 & 9 \\
\hline 5 & $\begin{array}{l}\text { Larix } \\
\text { regeneration } \\
\\
\left(\text { trees } \mathrm{ha}^{-1}\right)\end{array}$ & $\begin{array}{l}18.0^{* *} \\
(5.10)\end{array}$ & - & $\begin{array}{l}-12.3 \\
(6.30)\end{array}$ & - & $-25.7 * *(6.68)$ & - & $6.69(5.23)$ & $0.664(* *)$ & 18.7 & 10 \\
\hline 6 & $\begin{array}{l}\text { Organic layer } \\
\text { Thickness }(\mathrm{cm})^{1}\end{array}$ & $\begin{array}{l}9.94 * * \\
(0.34)\end{array}$ & - & $\begin{array}{l}1.34 * * \\
(0.39)\end{array}$ & $\begin{array}{l}-0.92 * \\
(0.404)\end{array}$ & $1.01 *(0.42)$ & - & $3.02 * *(0.37)$ & $0.90(*)$ & 1.29 & 10 \\
\hline 7 & $\begin{array}{l}\text { Organic layer } \\
\text { carbon }{ }^{1} \\
\left(\mathrm{~kg} \mathrm{C} \mathrm{m}^{2}\right)\end{array}$ & $\begin{array}{l}2.97 * * \\
(0.15)\end{array}$ & - & $\begin{array}{l}0.52 * \\
(0.17)\end{array}$ & $\begin{array}{l}-0.53^{* *} \\
(0.17)\end{array}$ & - & - & - & $0.71(* *)$ & 0.58 & 12 \\
\hline
\end{tabular}

1 Stand TG2-P1 was omitted, because it was subject to periodic floods removing the organic layer regularly.

2 Model is based on arcsine-transformed data.

3 Only advance regeneration $(>1.3 \mathrm{~m}$ height and $<7 \mathrm{~cm} \mathrm{DBH})$. 
Table 6. The fraction of trees affected by fungal wood rot as related to tree species and tree dimension.

\begin{tabular}{|c|c|c|c|c|c|c|c|c|c|c|c|c|}
\hline & \multicolumn{3}{|c|}{ Larix } & \multicolumn{3}{|c|}{ Picea } & \multicolumn{3}{|c|}{ Pinus } & \multicolumn{3}{|c|}{ Abies } \\
\hline & $n$ & healthy & rot & $n$ & healthy & rot & $n$ & healthy & rot & $n$ & healthy & rot \\
\hline & \multicolumn{3}{|c|}{$\%$} & \multicolumn{3}{|c|}{$\%$} & \multicolumn{3}{|c|}{$\%$} & & \multicolumn{2}{|l|}{$\%$} \\
\hline $\mathrm{DBH}<20 \mathrm{~cm}$ & 9 & 89 & 11 & 17 & 89 & 11 & 14 & 57 & 43 & 12 & 67 & 33 \\
\hline DBH $20-40 \mathrm{~cm}$ & 24 & 50 & 50 & 20 & 55 & 45 & 21 & 62 & 38 & 6 & 67 & 33 \\
\hline $\mathrm{DBH}>40 \mathrm{~cm}$ & 5 & 40 & 60 & 5 & 40 & 60 & 14 & 58 & 42 & 0 & 0 & 0 \\
\hline Total & 38 & 58 & 42 & 42 & 67 & 33 & 49 & 62 & 38 & 18 & 67 & 33 \\
\hline
\end{tabular}

increasingly dominant with a smaller fraction of Abies as the time without a surface fire increases. Single Larix trees may reach an age of more than 600 yrs. These trees survived the last stand-replacing fire and served as additional witnesses of the last major fire event. Thus, the change in species composition 200 to $300 \mathrm{yrs}$ after fire was due to competitive interaction between species, which were far below the maximum age of Larix. The change in species composition was related to the frequency and time since the last surface fire. The variation in stem biomass was particularly large in the transition phase 250 yrs after fire.

The question remains, if this increase in biomass may continue "forever". We doubt that biomass increases much beyond $130 \mathrm{tC} \mathrm{ha}^{-1}$ in this region. There is a biological reason that terminates biomass accumulation: fungal stem rot increased with age in all species (Table 6). The healthiest species was Picea obovata, closely followed by Pinus sibirica, with Larix being the most affected species. Averaged over the whole tree population about one third of the trees were affected by fungal rot. In the absence of fire, fungal rot of the heartwood would cause a turnover of the main canopy over time and limit biomass accumulation with Larix being most affected. Since Pinus and Picea regenerated continually under the main canopy, this would result in a constant biomass, with an age of the main canopy probably not exceeding 350 to 400 yrs.

\section{Discussion}

The aim of our study was to explore the relative roles of fire and climate related differences in growth performance of trees in determining the transition from the dark taiga in central Siberia to the Larix-dominated forests of eastern Siberia. Our results suggest that the evergreen conifers, Abies sibirica and Picea obovata, are the natural late-successional species both in central and eastern Siberia. Irrespective of longitudinal changes in climate an the presence of permafrost. They can grow and form dense and productive "dark taiga" stands far to the east of their present main distribution, provided there has been no fire for an extended period of time. Dark
Taiga stands are known to persist in the Larix forests region of the northern boreal forest of the Lower Tunguska on mountain ridges (Prokushkin, pers. communication) and on wet sites in the Lena basin of east Siberia (Schulze et al., 1995). We did not observe dramatic changes in indicators of adult growth performance. Juvenile growth of Larix was clearly higher in the eastern most site. This, however, may also be caused by the lower stand density following thinning by fires.

While the patterns we observe seemed to be strong and consistent, we are well aware of the limitations of our data set. To be able to test the "performance only" hypothesis it was necessary to harvest and core a large number of mature and regenerating trees. Testing the "fire only" hypothesis made it necessary to quantify a range of environmental covariates (active-layer depth, topography, hydrology status derived from vegetation surveys, etc.). This high sampling intensity per stand and the difficulty to reach sites in this region limited the number of stands that could be surveyed during our expedition $(n=16)$. In addition, old-growth stands are rare east of the Yenisei Ridge. Given these operational and natural limitations, it was important to locate mature stands covering a wide range of compositional differences and fire histories within walking distance of each other and the river. This was achieved by carrying out an in-depth analysis of remote sensing imagery and by consulting local experts.

The satellite imagery revealed that isolated old-growth forest areas, like the Vanavara site, with a high proportion of evergreen dark taiga species, are present among the Larixdominated forest of the Central-East Siberian Plateau. Close inspection of these stands in the field showed that they were neither edaphically nor topographically different from the surrounding Larix forest. For example, the two "dark taiga" stands in Vanavara (VA1-P2, VA1-P3) had an active-layer thickness of only $60 \mathrm{~cm}$ and yet reached a canopy height of 27-30 m, not much lower than the highly productive dark taiga sites along the River Yenisei (Schulze et al., 2005). These trees were still actively growing and had not reached their maximum height. If there was a physiological or morphological basis for the dominance of Larix in eastern Siberia and the disappearance of evergreen conifers this would be 
reflected by a decrease in performance of the latter relative to Larix towards the east. Our analysis of growth performance revealed that there were hardly any shifts in the performance rank for adult trees. The standardized relative radial increment $\left(\mathrm{RI}_{30}\right)$ even decreased for Larix towards the east, while it remained constant or showed no consistent pattern for the evergreen conifers.

As expected for a light-demanding pioneer species, Larix attained large diameters within 200 yrs $\left(D_{200}\right)$. However, it grew faster in all sites and no substantial shifts in the ranking were observed along the transect. Only the absolute growth rates across all species decreased towards the east. These findings with respect to mature trees lend little support to Hypothesis 1 ("performance only").

However, for the relative radial increment of young trees $\left(\mathrm{RI}_{\mathrm{y}}\right)$, we did find a trend for a relative advantage of Larix towards the east, but this may also be due to enhanced height growth with competition in the early regeneration phase.

Growth rates are only one component of performance. Recruitment and mortality are two additional processes controlling a species' success in a community (Pacala et al., 1996). Quantifying these processes usually requires repeated inventories. Snapshot inventories like ours can only yield proxies. Mortality rates were approximated for the evergreen conifers as the percentage of dead individuals in the pole stage, which was highly variable $(29 \pm 28 \%)$ and did not show any longitudinal trend. Recruitment rates, approximated simply as the sapling density, also did not change along the transect and were on average a factor five higher for the evergreen conifers as compared to Larix. In summary, there is little evidence that performance of evergreen conifers as quantified in mature forests decreases to an extent that would not allow them to successfully compete towards the east of the transect.

Why is it then, that Larix is the dominating species towards the east? The most important predictor of the percentage of dark taiga conifers in mature stands is the time since the last fire. The longer the time since the last fire, the higher the fraction of dark taiga species with the opposite being the case for the fraction of Larix. It is important to note that edaphic factors did not explain the composition, or only to a minor extent. This indicates that the "dark taiga" forests in Bajkit and Vanavara cannot be explained by edaphic/topographic peculiarities, such as steep southern slopes or the vicinity of rivers with deeper active layers. The reason for the negative effect of fire on the occurrence of evergreen conifers is their low fire tolerance. Wirth (2005) distinguished between fire sensitive and fire tolerant boreal species, with Larix and Pinus sylvestris being fire tolerant. These species regenerate after fire in dense cohorts. Therefore they shed their lower branches at an early stage and do not provide a "fuel-ladder" for surface fires to reach the crown. The most sensitive stages are the thickets of regeneration. In these thickets fire acts as thinning agent. In contrast, Abies and Picea do not shed the lower branches. Thus fire can climb into the crown along this "fuel-ladder" and cause the devastating effects of a hot crown fire. In addition, they lack thick insulating bark that protects the cambium of Larix and Pinus sylvestris against heat damage. The natural frequency of stand-replacing fires appears to be fairly low in the study region ( $130 \mathrm{yrs})$ compared to eastern Larix-dominated forest (Achard et al., 2006). This confirms the observations made by Kharuk et al. (2005a) in the northern Tunguska and in other remote areas (Achard et al., 2008; Mollicone et al., 2006).

There is an increased chance of a second fire, following a stand-replacing event, after 40 to $50 \mathrm{yrs}$ when the fire succession has reached its highest density for a Larix dominated thicket. This second fire has a thinning effect and it thus may in fact enhance stand growth. One stand-replacing fire every 100 to 200 yrs would maintain a Larix-dominated vegetation. Only if the mean fire frequency increases beyond $300 \mathrm{yrs}$ as in the mountains of the Yenisei Ridge (Mollicone et al., 2002; Schulze et al., 2002) there is a chance for dark taiga species to become dominant at a regional level (Fig. 2g, 3f, 7e). Thus, fire (Hypothesis 1) appears to be the main driver for Larix dominance and the suppression of evergreen conifers.

However, there are additional factors determining the extent of the evergreen contribution. Longitude appeared to be another predictor of the fraction of dark taiga species. In contrast to Lloyd et al. (2011) we did not observe a latitudinal effect. At a given time-since-fire, the Vanavara sites show a significantly lower fraction of evergreen conifers. In fact, there are no pure dark taiga forests in Vanvara, but rather mixtures of Picea, Pinus and Larix. However, this could also be an indirect consequence of fire, such as seed limitation. This needs further investigation.

The mean fire-return interval is related to longitude (Fig. 7b), but not to the time since the last fire. Our study was not designed to investigate the causes of fire frequency and the stands were not randomly in the landscape. Nevertheless, the time since the last fire correlated with precipitation, explaining about 40 to $50 \%$ of the variation, and with standing biomass. Our study did not quantify the humaninduced fires (Mollicone et al., 2006) which could uncouple fire frequency from climate. Human induced fires would promote the fire-tolerant species beyond climatic drought limits. Based on human population density, the Tunguska canyon is most likely the least affected by humans. Thus, human induced fires would again correlate with precipitation. Also, despite an observed increase in precipitation in northern latitudes of Siberia (Kharuk et al., 2005b) we think that the effect on conifer distribution will be compensated by an expected increase in anthropogenic fires (Mollicone et al., 2006). In the present study the time for fire-returns emerges as the controlling factor explaining the fraction of light versus dark taiga, even though an interaction with climate exists through "continentality". Periods of hydrological drought would promote fires more than temperature. Table 5 shows that the biomass fraction of dark and light taiga species were stronger correlated with the time since the last fire than with climate as expressed by longitude. The interaction of fire frequency 
with human activities (population, hunting, fishing, tourism) can only be resolved by a separate modeling activity.

Thornley and Cannell (2004) predicted that increasing fire frequency may reduce NPP. However, our data do not indicate such a change in productivity with fire frequency. We do not observe an age-related decline in the productivity of unburnt stands. Net biomass increase is constant (about $0.4 \mathrm{tC} \mathrm{ha}^{-1} \mathrm{yr}^{-1}$ ) over $350 \mathrm{yrs}$ of observed stand ages. Also at the single-tree level, there is no clear sign of an age-related decline of old trees (Luyssaert et al., 2008; Di Filippo et al., 2012), which is in contrast to observations in age-class forests (Mencuccini et al., 2005). Young trees do not grow faster than old trees did when they where young, i.e. there was no sign of higher growth of young stands at the stand level. Our inventory data cannot detect effects of recent temperature change.

The upper age and biomass of old-growth Siberian forest seem to be set neither by fire frequency nor by climate change, but by fungal rot of heartwood in old trees. All species were affected by fungal rot eventually and it appears that wood-decomposing fungi set the upper limit for the accumulation of biomass. Larix was affected the most by fungal rot and thus fails in old stands in absence of fire induced regeneration. In natural stands, the decay of single canopy trees due to fungal rot of the main stem would not affect productivity due to the permanent regeneration of evergreen species in the sub-canopy.

The change from deciduous to evergreen species takes place not at the end of the life-expectancy of Larix, but much earlier. Apparently it is mainly determined by the regeneration requirements of the different species, and Larix has a serious disadvantage for regeneration if there is no fire for more than 100 yrs. With respect to global change, climate seems to be of lesser importance than landuse in determining the deciduous-evergreen boundary in future, because fire frequency is increasingly determined by anthropogenic activities.

Although our findings are confined to the Podkamennaia Tunguska basin there are indications that the general principles hold beyond this region. Kharuk et al. (2011) explain the distribution of Larix in the northern boreal region ( $66^{\circ}$ to $71^{\circ}$ north) also by fire regime changes. Schulze et al. (1995) made similar observations in the eastern Siberian Larix forests of the Lena basin. South of the Podkamennaia Tunguska Pinus sylvestis replaces Larix on podolized alluvial sands of the Angara, which is similar to the fire prone Pinus sylvestris forests on the west side of the Yenisei. Pinus sylvestris with its deep taprot replaces Larix on nutrient poor sites with no permafrost, while Larix with its adventitious roots is dominant on nutrient rich shallow soils with permafrost. Thus, we think, that the role of fire in shaping the land cover is important on a larger scale in Siberia.

\section{Conclusions}

- Tree performance could not explain the longitudinal gradient in forest composition.

- Fire appears as the main factor controlling the deciduous to evergreen ratio.

- Dark taiga species can persist far to the east of their natural main distribution, provided there is no fire. It is most likely, that human-induced fires will expand the region of fire-tolerant light taiga species (Larix spec. and Pinus sylvestris).

- There is a constant net biomass increase over $350 \mathrm{yrs}$ and no age-related decline of single trees or of forest stands. The upper limit of accumulated biomass is set by wood-decomposing fungi.

Acknowledgements. We thank Annett Börner for her help with the artwork, and Dominik Hessenmöller for his help. We also thank Inge Schulze for all her support during the fieldwork. The data processing was supported by the Russian "Megagrant" 11.G34.31.0014 from 30 November 2010 to E. D. Schulze by the Russian Federation and the Siberian Federal University to support research projects by leading scientists at Russian Institutions of higher Education.

Edited by: K. Thonicke

The service charges for this open access publication have been covered by the Max Planck Society.

\section{References}

Achard, F., Mollicone, D., and Stibig, H. J.: Areas of rapid forestcover change in boreal Eurasia, Forest Ecol. Manag., 237, 322334, 2006.

Achard, F., Eva, H. D., Mollicone, D., and Beuchle, R.: The effect of climate anomalies and human ignition factor on wildfires in Russian boreal forests, Philos. T. R. Soc. B, 363, 2331-2339, 2008.

Bartalev, S., Erchov D., Isaev, A., and Belward, A.: A new SPOT4Vegetation derived land cover map of Northern Eurasia. Int. J. Remote Se., 24, 1977-1982, 2003.

Beer, C., Lucht, W., Gerten, D., Thonicke, K., and Schmullius, C.: Effects of soil freezing and thawing on vegetation carbon density in Siberia: A modeling analysis with the Lund-Potsdam-Jena Dynamic Global Vegetation Model (LPJ-DVGM), Global Biogeochem. Cy., 21, GB1012, doi:10.1029/2006GB002760, 2007.

Bond-Lamberty, B., Peckham, S. D., Ahl, D. E., and Gower, S. T.: Fire as the dominant driver of central Canadian boreal forest carbon balance, Nature, 450, 89-92, 2007.

Canham, C. D.: An index for understory light levels in and around canopy gaps, Ecology, 69, 1634-1638, 1988.

Di Filippo, A. Biondi, F., Maugeri, M., Schirone, B., and Piovesan, G.: Biocliimate and growth history affect beech lifespan in the Italian Alps and Apeninnes, Glob. Change Biol., 18, 960-972, 2012. 
Grissino-Mayer, H. D.: Evaluating crossdating accuracy: a manual and tutorial for the computer program COFECHA, Tree-Ring Res., 57, 205-221, 2001.

Isaev, A. S. (Ed.): Forest Map of USSR at scale 1:2500000, State committee of the USSR, Moscow, 1990.

Kelliher, F. M., Hollinger, D. Y., and Schulze, E. D.: Evaporation from an eastern Siberian larch forest, Agr. Forest Meteorol., 85, 135-147, 1997.

Kharuk, V. I., Dvinskaya, M. L., and Ranson, K. J.: The spatiotemporal pattern of fires in northern taiga larch forests of Central Siberia, Russ. J. Ecol., 36, 302-311, 2005a.

Kharuk, V. I., Dvinskaya, M. L., Ranson, K. J., and Im, S. T.: Expansion of evergreen conifers to the larch-dominated zone and climatic trends, Russ. J. Ecol., 36, 164-170, 2005 b.

Kharuk, V. I., Ranson, K. J., Dvinskaya, M. L., and Im, S. T.: Wildfires in northern Siberian larch dominated communities, Environ. Res. Letters, 6, 045208 (6 pp.), doi:10.1088/17489326/6/4/045208, 2011.

Kondrotiva, K. A.: Thickness of Permafrost in the USSR, Kryogeographic maps of Russia, 1:2.5 Million, Leningrad, 1986.

Krinner, G., Viovy, N., Noblet-Ducoudré, N. de, Ogée, J., Plocher, J., Friedlingstein, P., Ciais, P., Sitch, S., and Prentice, I. C.: A dynamic global vegetation model for studies of the coupled atmosphere-biosphere system, Global Biogeochem. Cy., 19, GB1015, doi:10.1029/2003GB002199, 2005.

Lloyd, A. H., Bunn, A. G., and Berner, L.: A latitudinal gradient in tree growth response to climate warming in the Siberian taiga, Glob. Change Biol., 17, 1935-1945, 2011.

Lunn, D. J., Thomas, A., Best, N., and Spiegelhalter, D.: WinBUGS - A Bayesian modelling framework: Concepts, structure, and extensibility, Stat. Comput., 10, 325-337, 2000.

Luyssaert, S., Schulze, E. D., and Boerner, A.: Old-growth forests as global carbon sinks, Nature, 455, 213-215, 2008.

Mencuccini, M., Martínez-Vilalta, J., Vanderklein, D., Hamid, H. A., Korakaki, E., Lee, S., and Michiels, B.: Size-mediated ageing reduces vigour in trees, Ecol. Lett., 8, 1183-1190, 2005.

Mollicone, D.: A new remote sensing based methodology to determine fire frequency and forest succession in the boreal forest, unpublished Ph.D. Thesis, University of Padova, 2002.

Mollicone, D., Achard, F., and Marchesini, L. B.: A remote sensing based approach to determine forest fire cycle: Case study of the Yenisei ridge dark taiga, Tellus B, 54, 688-695, 2002.

Mollicone, D., Eva, H. D., and Achard, F.: Ecology: Human role in Russian wild fires, Nature, 440, 436-437, 2006.

Nikolov, N. and Halmisaari, H.: Silvics of the circumpolar boreal tree species, in: A systems analysis of the global boreal forest, edited by: Shugrat, H. H., Leemans, R., and Bonan, G. B., 1384, Cambridge University Press, Cambridge, 1992.

Pacala, S. W., Canham, C. D., Saponara, J., Silander Jr., J. A., Kobe, R. K., and Ribbens, E.: Forest models defined by field measurements: estimation, error analysis and dynamics, Ecol. Monogr., 66, 1-43, 1996.

Sato, H., Itoh, A., and Kohyama, T.: SEIB-DCVM: A new Dynamic Global Vegetation Model using a spatially explicit individualbased approach, Ecol. Modell., 200, 279-307, 2007.

Schulze, E. D.: Plant life forms and their carbon, water and nutrient relations, in: Encyclopedia of Plant Physiology. Physiological Plant Ecology II. Vol. 12B, Water relations and photosynthetic productivity, edited by: Lange, O. L., Nobel, P. S., Osmond, C.
B., and Ziegler, H., 615-676, Springer, Berlin, 1982.

Schulze, E. D., Schulze, W., and Kelliher, F. M.: Aboveground biomass and nitrogen nutrition in a chronosequence of pristine Dahurian Larix stands in eastern Siberia, Can. J. Forest Res., 25, 943-960, 1995.

Schulze, E. D., Prokuschkin, A., Arneth, A., Knorre, N., and Vaganov, E. A.: Net ecosystem productivity and peat accumulation in a Siberian Aapa mire, Tellus B, 54, 531-536, 2002.

Schulze, E. D., Wirth, C., Mollicone, D., and Ziegler, W.: Succession after stand replacing disturbances by fire, wind throw, and insects in the dark Taiga of Central Siberia, Oecologia, 146, 77$88,2005$.

Shibistov, B. and Schulze, E. D.: Geology and landscapes of the Central Siberia, Museum of Geology of Central Siberia,Krasnoyarsk, 181 pp., 2007.

Shuman, J. K., Shugart, H. H., and O'Halloran, T. L.: Sensitivity of Siberian larch forests to climate change, Glob. Change Biol., 17, 2370-2384, doi:10.1111/j.1365-2486.2011.02417.x, 2011.

Sitch, S., Smith, B., and Prentice, I. C.: Evaluation of ecosystem dynamics, plant geography and terrestrial carbon cycling in the LPJ dynamic global vegetation model, Glob. Change Biol., 9, 161-185, 2003.

Sugimoto, A., Yanagisawa, N., Naito, D., Fujita, N., and Maximov, T. C.: Importance of permafrost as a source of water for plants in east Siberian taiga, Ecol. Res., 17, 493-503, 2002.

Thonicke, K., Spessa, A., Prentice, I. C., Harrison, S. P., Dong, L., and Carmona-Moreno, C.: The influence of vegetation, fire spread and fire behaviour on biomass burning and trace gas emissions: results from a process-based model, Biogeosciences, 7, 1991-2011, doi:10.5194/bg-7-1991-2010, 2010.

Thornley, J. H. M. and Cannell, M. G. R.: Long-term effects of fire frequency on carbon storage and productivity of boreal forests: A modeling study, Tree Physiol., 24, 765-773, 2004.

von Lüpke, N.: The reasons for the change of vegetation of Siberian larch and spruce forests using tree ring analysis, Thesis, University of Göttingen, 61 pp., 2006.

Walter, H.: Die Vegetation Osteuropas, Nord- und Zentralaasiens, Gustav Fischer Verlag, Stuttgart, 452 pp., 1974.

Wirth, C.: Fire Regime and Tree Diversity in Boreal Forests: Implications for the Carbon Cycle, in: Forest Diversity and Function, edited by: Scherer-Lorenzen, M., Körner, C., and Schulze, E.-D., Springer, Berlin Heidelberg, 309-344, 2005.

Wirth, C., Schulze, E. D., and von Stünzner-Karbe, D.: Aboveground biomass and structure of pristine Siberian Scots pine forests as controlled by competition and fire, Oecologia, 121, 66-80, 1999.

Wirth, C., Schulze, E.-D., Lühker, B., Grigoriev, S., Siry, M., Hardes, G., Ziegler, W., Backor, M., Bauer, G., and Vygodskaya, N.N.: Fire and site type effects on the long-term carbon balance in pristine Siberian Scots Pine forests, Plant Soil, 242, 41-63, 2002.

Xiaodong, Y. and Shugrat, H. H.: FAREAST: a forest gap model to simulate dynamics and patterns of eastern European forests, J. Biogeogr., 32, 1641-1658, 2005. 